\title{
Ecology of phlebotomine sandflies and putative reservoir hosts of leishmaniasis in a border area in Northeastern Mexico: implications for the risk of transmission of Leishmania mexicana in Mexico and the USA
}

Jorge J. Rodríguez-Rojas ${ }^{1}$, Ángel Rodríguez-Moreno², Miriam Berzunza-Cruz ${ }^{3}$, Gabriel Gutiérrez-Granados ${ }^{4}$, Ingeborg Becker ${ }^{3}$, Victor Sánchez-Cordero ${ }^{2}$, Christopher R. Stephens ${ }^{5,6}$, Ildefonso Fernández-Salas ${ }^{1,7,8}$, and Eduardo A. Rebollar-Téllez ${ }^{1,7, *}$

1 Laboratorio de Entomología Médica, Departamento de Zoología de Invertebrados, Facultad de Ciencias Biológicas, Universidad Autónoma de Nuevo León, Av. Universidad S/N, Cd. Universitaria, C.P. 66450, San Nicolás de los Garza, Nuevo León, México

2 Departamento de Zoología Instituto de Biología, Universidad Nacional Autónoma de México, Circuito Exterior S/N, C.P. 04510, Coyoacán, Ciudad de México, México

3 Unidad de Investigación en Medicina Experimental, Facultad de Medicina, Universidad Nacional Autónoma de México, Dr. Balmis \#148, Colonia Doctores, C.P. 06726, Ciudad de México, México

${ }^{4}$ Facultad de Estudios Superiores Zaragoza, Universidad Nacional Autónoma de México, Batalla 5 de mayo S/N esquina Fuerte de Loreto, Col. Ejército de Oriente, Iztapalapa, C.P. 09230, Ciudad de México, México

5 Centro de Ciencias de la Complejidad, Universidad Nacional Autónoma de México, Circuito Exterior S/N. C.P. 04510, Cd. Universitaria, Ciudad de México, México

${ }^{6}$ Instituto de Ciencias Nucleares, Universidad Nacional Autónoma de México, Circuito Exterior S/N. C.P. 04510, Coyoacán, Ciudad de México, México

7 Centro de Investigación en Ciencias de la Salud, Universidad Autónoma de Nuevo León, Av. Carlos Canseco S/N. C.P. 64460, Mitras Centro, Monterrey, Nuevo León, México

${ }^{8}$ Centro Regional de Investigación en Salud Pública, Instituto Nacional de Salud Pública, 19 Poniente Esquina $4^{\mathrm{a}}$ Norte S/N., C.P. 30700 , Centro Tapachula, Chiapas, México

Received 8 April 2017, Accepted 27 July 2017, Published online 21 August 2017

\begin{abstract}
Leishmaniases are a group of important diseases transmitted to humans through the bite of sandfly vectors. Several forms of leishmaniases are endemic in Mexico and especially in the Southeast region. In the Northeastern region, however, there have only been isolated reports of cases and scanty records of sandfly vectors. The main objective of this study was to analyze the diversity of sandflies and potential reservoir hosts of Leishmania spp. in the states of Nuevo León and Tamaulipas. Species richness and abundances of sandflies and rodents were recorded. A fraction of the caught sandflies was analyzed by PCR to detect Leishmania spp. Tissues from captured rodents were also screened for infection. Ecological Niche Models (ENMs) were computed for species of rodent and their association with crop-growing areas. We found 13 species of sandflies, several of which are first records for this region. Medically important species such as Lutzomyia anthophora, Lutzomyia diabolica, Lutzomyia cruciata, and Lutzomyia shannoni were documented. Leishmania spp. infection was not detected in sandflies. Nine species of rodents were recorded, and Leishmania (Leishmania) mexicana infection was found in four species of Peromyscus and Sigmodon. ENMs showed that potential distribution of rodent pest species overlaps with allocated crop areas. This shows that Leishmania (L.) mexicana infection is present in the Northeastern region of Mexico, and that previously unrecorded sandfly species occur in the same areas. These findings suggest a potential risk of transmission of Leishmania (L.) mexicana.
\end{abstract}

${ }^{*}$ Corresponding author: eduardo.rebollartl@uanl.edu.mx

SOPS 4 Special Issue - ISOPS IX - International Symposium on Phlebotomine Sandflies.

Invited Editors: Jérôme Depaquit, Bernard Pesson, Denis Augot, James Gordon Campbell Hamilton, Phillip Lawyer, and Nicole Léger

This is an Open Access article distributed under the terms of the Creative Commons Attribution License (http://creativecommons.org/licenses/by/4.0), which permits unrestricted use, distribution, and reproduction in any medium, provided the original work is properly cited. 


\begin{abstract}
Résumé - Écologie des phlébotomes et hôtes putatifs de la leishmaniose dans une zone frontalière du nord-est du Mexique : implications pour le risque de transmission de Leishmania mexicana au Mexique et aux États-Unis. Les leishmanioses sont un groupe de maladies importantes transmises aux humains par piqûre des phlébotomes vecteurs. Plusieurs formes de leishmanioses sont endémiques au Mexique, surtout dans la région du sud-est. Dans la région du nord-est, cependant, il n'y a eu que des rapports isolés de cas et quelques signalements de phlébotomes. L'objectif principal de cette étude était d'analyser la diversité des phlébotomes et des hôtesréservoirs potentiels de Leishmania spp. dans les états de Nuevo León et Tamaulipas. La richesse en espèces et l'abondance des phlébotomes et des rongeurs ont été étudiées. Une fraction des phlébotomes capturés a été analysée par PCR pour détecter les Leishmania spp. Les tissus des rongeurs capturés ont également été criblés pour détecter une infection. Les modèles de niches écologiques (ENM) ont été calculés pour les espèces de rongeurs et leur association avec les zones cultivées. Nous avons trouvé treize espèces de phlébotomes, dont plusieurs sont des premières mentions pour cette région. Des espèces médicalement importantes telles que Lutzomyia anthophora, Lutzomyia diabolica, Lutzomyia cruciata et Lutzomyia shannoni ont été documentées. L'infection par Leishmania spp. n'a pas été détectée chez les phlébotomes. Neuf espèces de rongeurs ont été collectées, et une infection par Leishmania (Leishmania) mexicana a été trouvée chez quatre espèces de Peromyscus et Sigmodon. L'ENM a montré que la répartition potentielle des espèces de rongeurs chevauche les zones allouées aux cultures. Cela montre que l'infection à Leishmania (L.) mexicana est présente dans la région nord-est du Mexique et que des espèces de phlébotomes précédemment non mentionnées se trouvent dans les mêmes zones. Ces résultats suggèrent un risque potentiel de transmission de Leishmania (L.) mexicana.
\end{abstract}

\section{Introduction}

Human leishmaniases represent a health problem in many countries worldwide. It is estimated that the diseases are prevalent in at least 98 countries, with $1.5-2.0$ million persons infected and over 350 million persons living at risk [1]. In Mexico, four clinical forms of the disease have been reported, localized cutaneous leishmaniasis (LCL), diffuse cutaneous leishmaniasis (DCL), mucocutaneous leishmaniasis (MCL), and visceral leishmaniasis (VL), with LCL being by far the most common clinical manifestation [88]. Transmission of Leishmania spp. to humans occurs by the infectious bites of several species of the genus Lutzomyia França [4, 57, 59, 73]. Up until now, most of the field studies concerning LCL in Mexico were conducted in the Yucatan Peninsula. These studies include entomological aspects [67-70], reservoir hosts $[5,83,84]$, and clinical approaches $[2,30,85]$.

Traditionally it has been assumed that the only proven vector of Leishmania (L.) mexicana in Mexico is the sandfly Lutzomyia olmeca olmeca (Vargas and Díaz-Nájera) [4], although in more recent studies, we have found evidence in the Yucatan Peninsula that other species such as Lu. cruciata (Coquillett), Lutzomyia shannoni (Dyar), and Lutzomyia panamensis (Shannon) may actually be acting as vectors as well $[57,59,73]$. These entomological studies were carried out in the Yucatan Peninsula. Unfortunately, there has been very little research in other regions of the country, even though cases of leishmaniasis have been reported there. A recent publication by González-Rosas et al. [26] revealed using Ecological Niche Modeling that the distribution of leishmaniasis in Mexico does not correlate well with the distribution area of the proven sandfly vector $L$. olmeca olmeca. These findings clearly suggest that other sandfly vectors - and possibly other reservoir hosts - are implicated in the transmission cycle in other foci of leishmaniasis.

To date, studies of leishmaniasis in Northeastern Mexico (NEM) have been very scanty and composed mainly of old records scattered across different geographical areas. From the clinical perspective, perhaps the first documented autochthonous case of leishmaniasis in NEM was reported by Ramos-Aguirre [64] in a six-year-old girl from the state of Coahuila. A case of DCL was identified in San Benito, Texas, USA [75]. However, in this study, it could not be established whether or not the case was autochthonous to the USA, as the 64-year-old infected woman reported frequent visits to the Mexican states of Nuevo León and Tamaulipas. In the state of Coahuila, Ramos-Aguirre [65] reported two additional cases of DCL: one was a 24-year-old male from the county of Múzquiz, whereas the second case was a 23-year-old male from the same county. At the University Hospital in Monterrey, state of Nuevo León, Welsh [89] reported one case of LCL in a 2-year-old male toddler who had always lived in the county of San Carlos, state of Tamaulipas. Several years later, VelascoCastrejón et al. [88] reported six additional cases of DCL in Mexico; of those, three were from the NEM region: one from Tamaulipas (patient no. 4: a 15-year-old male), and two from the state of Coahuila (patient no. 5: a 40-year-old male and patient no. 6: a 17-year-old male). González-Piñeyro et al. [25] reported an 8-year-old patient from Nuevo León. Finally, a more recent report of cutaneous leishmaniasis concerns an unpublished case treated at the University Hospital in the city of Monterrey, corresponding to a 38-year-old male from the town of Méndez, Tamaulipas. So far, there have been at least seven cases in NEM reported officially; in addition; two recent suspected cases are being considered from the county of Guadalupe, in the state of Nuevo León (Dr. Nancy Treviño of the Health Secretariat of Mexico, per. com.).

Up to now, sandfly occurrences in NEM have been very limited and collection data are available in only a few publications [e.g. 16, 24, 86, 92]. The oldest known specimens are from collections made in 1936 in Tamaulipas by C. Plumer (see [86], for collection details). In addition to the published records, there are a small number of unpublished collections carried out by Rebollar-Téllez from 1993 and 2010. Adding up all these sandfly records, we determined that 52 specimens (34 ô and 18 o) of only five sandfly species (Lu. anthophora (Addis), 
Table 1. Name and geographic location of the selected sampling sites in the states of Nuevo León and Tamaulipas, Mexico. Collection dates at each site are also listed.

\begin{tabular}{|c|c|c|c|c|c|}
\hline State & Municipality & Location & Date & Altitude ( $\mathrm{m}$ asl) & Coordinates \\
\hline \multirow[t]{5}{*}{ Nuevo León } & Linares & Rancho San Manuel & 06-08/Apr/2010 & 446 & $24^{\circ} 40^{\prime} 08^{\prime \prime} \mathrm{N} ; 099^{\circ} 36^{\prime} 16^{\prime \prime} \mathrm{W}$ \\
\hline & Escobedo & $\begin{array}{l}\text { Ejido San Nicolas, Predio } \\
\text { Colectivo Viejo }\end{array}$ & 05-07/May/2010 & 447 & $25^{\circ} 48^{\prime} 22^{\prime \prime} \mathrm{N} ; 100^{\circ} 17^{\prime} 17^{\prime \prime} \mathrm{W}$ \\
\hline & Santiago & Cienega de Gonzalez & $20-22 / J u n / 2010$ & 1304 & $25^{\circ} 22^{\prime} 39^{\prime \prime} \mathrm{N} ; 100^{\circ} 14^{\prime} 31^{\prime \prime} \mathrm{W}$ \\
\hline & Mina & Ejido Labores del Ojo & $12-14 / \mathrm{Jul} / 2010$ & 574 & $26^{\circ} 00^{\prime} 04^{\prime \prime} \mathrm{N} ; 100^{\circ} 30^{\prime} 40^{\prime \prime} \mathrm{W}$ \\
\hline & Cadereyta Jiménez & $\begin{array}{l}\text { Fraccionamiento Rincon de los } \\
\text { Sabinos } 2^{\circ} \text { Sector }\end{array}$ & 27-29/Aug/2010 & 325 & $25^{\circ} 25^{\prime} 35^{\prime \prime} \mathrm{N} ; 099^{\circ} 58^{\prime} 23^{\prime \prime} \mathrm{W}$ \\
\hline Tamaulipas & Gómez Farías & Gómez Farías & $28-30 / \mathrm{Jul} / 2010$ & 347 & $23^{\circ} 04^{\prime} 17^{\prime \prime} \mathrm{N} ; 099^{\circ} 10^{\prime} 16^{\prime \prime} \mathrm{W}$ \\
\hline
\end{tabular}

Note. $\mathrm{m}$ asl: meters above sea level.

Lu. cruciata, Lu. diabolica (Hall), Lutzomyia oppidana (Dampf), and Lutzomyia texana (Dampf)) have been recorded in nine different localities. It is therefore clear that there has been very little accumulation of knowledge on sandfly species in NEM over the last 74 years (1936-2010).

Similarly, knowledge on reservoir hosts in NEM is basically nil, and the only relevant paper is that of [94], in which the authors reported a 6-year-old English Bull Terrier infected with visceral leishmaniasis. This report is not likely to be an autochthonous case as the dog was brought to Mexico from Aragón in Spain.

The results we present here are in fact part of a larger network of multi-disciplinary and inter-institutional collaborations in Mexico concerned with zoonoses and, in particular, leishmaniasis. This network has several nodes in different geographical areas throughout the country. This particular study was conducted in the northern node of this network. Having observed that the available information on leishmaniases was so scattered (spatially and temporally), the lack of information about vectors and potential reservoir hosts and their distributions, coupled with the increasing number of clinical cases of leishmaniasis occurring in the southern USA, we decided to conduct this study. Due to the aforementioned facts, in the present work we hypothesized that the distribution of phlebotomine sandflies and rodents in Northeastern Mexico has not been properly documented, and in the context of an ecological niche, it is predicted that there is an association between vector species and reservoir hosts of Leishmania spp. Therefore, we began a systematic field study with the following objectives: (i) to analyze the diversity of phlebotomine sandfly and small rodents in Northeastern Mexico, (ii) to search for Leishmania spp. infection among samples of sandflies and rodents in Northeastern Mexico, and (iii) to develop a model for the potential distribution of trapped rodents using ENMs to estimate the potential risk of Leishmania spp. disease when these hosts become crop pests.

\section{Material and methods}

\section{Description of study sites}

During the period between April and August 2010, we conducted fieldwork in five different localities in the states of Nuevo León (Linares, Escobedo, Santiago, and Cadereyta
Jiménez) and Tamaulipas (Gómez Farías) (Table 1, Fig. 1). Biogeographically, the states of Nuevo León and Tamaulipas are considered to be part of the Nearctic region with four different provinces: Altiplano, Tamaulipas, Sierra Madre Oriental, and Gulf of Mexico [55]. A brief description of each study site is as follows. Linares: weather is classified as semiwarm dry $\left(\mathrm{BS}_{1} \mathrm{hw}\right)$ with summer rains, mean annual temperature $22{ }^{\circ} \mathrm{C}$, and a total rainfall of $749 \mathrm{~mm}$ [23]. Vegetation in the area is composed of sub-mountain shrubs, mainly Helietta parvifolia Gray, Prosopis glandulosa Torr, Acacia farnesiana Linnaeus, and Acacia rigidula Benth [71] (Figs. 2A and 2B). Escobedo: weather is warm dry $\left(\mathrm{BS}_{1}\left(\mathrm{~h}^{\prime}\right) \mathrm{h}\right)$, mean annual temperature of $22-24{ }^{\circ} \mathrm{C}$, and a total rainfall of $400-600 \mathrm{~mm}$ [23]. This site is an agricultural area of sorghum and oak with remnant trees Prosopis glandulosa, Ehretia anacua Teran and Berland, Parkinsonia aculeata Linnaeus, and Pithecellobium ebano Berland [71] (Figs. 2C and 2D). Santiago: weather is classified as semi-warm humid ((A) $\left.\mathrm{C}_{1} \mathrm{a}\right)$, the mean annual temperature is $20.9^{\circ} \mathrm{C}$, with an annual rainfall of $1015 \mathrm{~mm}$ [23]. This site is located in the Ciénega de González forest of the mountain chain known as the Sierra Madre Oriental. Dominant tree species are pines and oaks, such as Quercus rysophylla Weath, Quercus laeta Liebm, Quercus polymorpha Schlecht and Cham, Pinus teocote Schlecht and Cham, and Pinus pseudostrobus Lindl [71] (Figs. 2E and 2F). Mina: weather is classified as warm dry $\left(\mathrm{BS}_{1}\left(\mathrm{~h}^{\prime}\right) \mathrm{h}\right)$ with an annual temperature of $24{ }^{\circ} \mathrm{C}$ and an annual rainfall of $270 \mathrm{~mm}$ [23]. Vegetation at this site is composed of xerophytes: Acacia berlandieri Benth, Cordia boissieri A. DC., Agave lechuguilla Torrey, Prosopis glandulosa, and several species of Opuntia spp. [71] (Figs. 2G and 2H). Cadereyta Jiménez: weather is semi-warm dry $\left(\mathrm{BS}_{1} \mathrm{hw}\right)$, with an annual temperature of $23{ }^{\circ} \mathrm{C}$ and an annual rainfall of $601-800 \mathrm{~mm}$ [71]. The study site is composed of suburban settlements surrounded by agriculture and secondary patches of vegetation containing Prosopis glandulosa, Acacia farnesiana, Ehretia anacua, and Pithecellobium ebano [71] (Figs. 2I and 2J). Gómez Farías: since this site is located in the transition between the Nearctic and Neotropical biotic provinces, it is classified as semi-warm humid $\left((\mathrm{A}) \mathrm{C}_{1}\right)$, the mean annual temperature is $21{ }^{\circ} \mathrm{C}$ with an annual rainfall of $1558-1778 \mathrm{~mm}$ [23]. Tree species are Mangifera indica Linnaeus, Ceiba pentandra Linnaeus, Brosimum alicastrum Swartz, and Mirandaceltis monoica Greene [71] (Figs. 2K and 2L). 


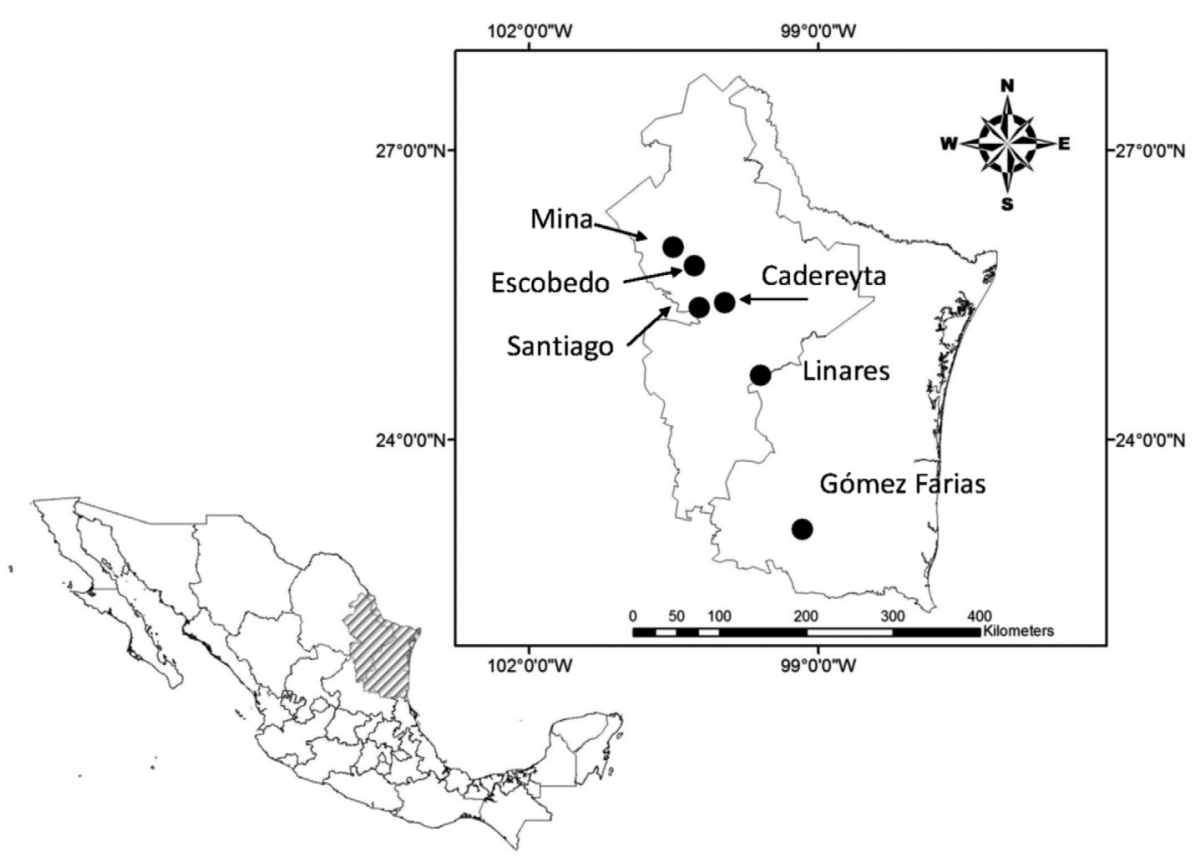

Figure 1. Geographical location of the sampling sites in the states of Nuevo León and Tamaulipas, Mexico.
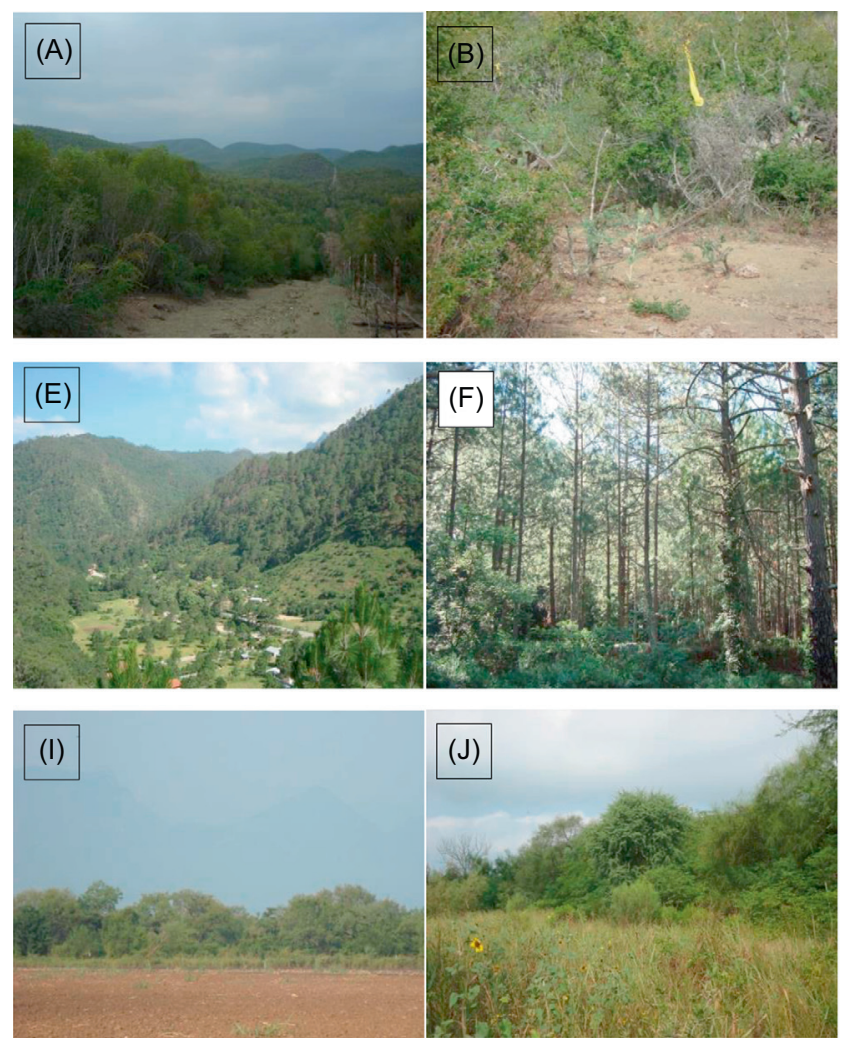
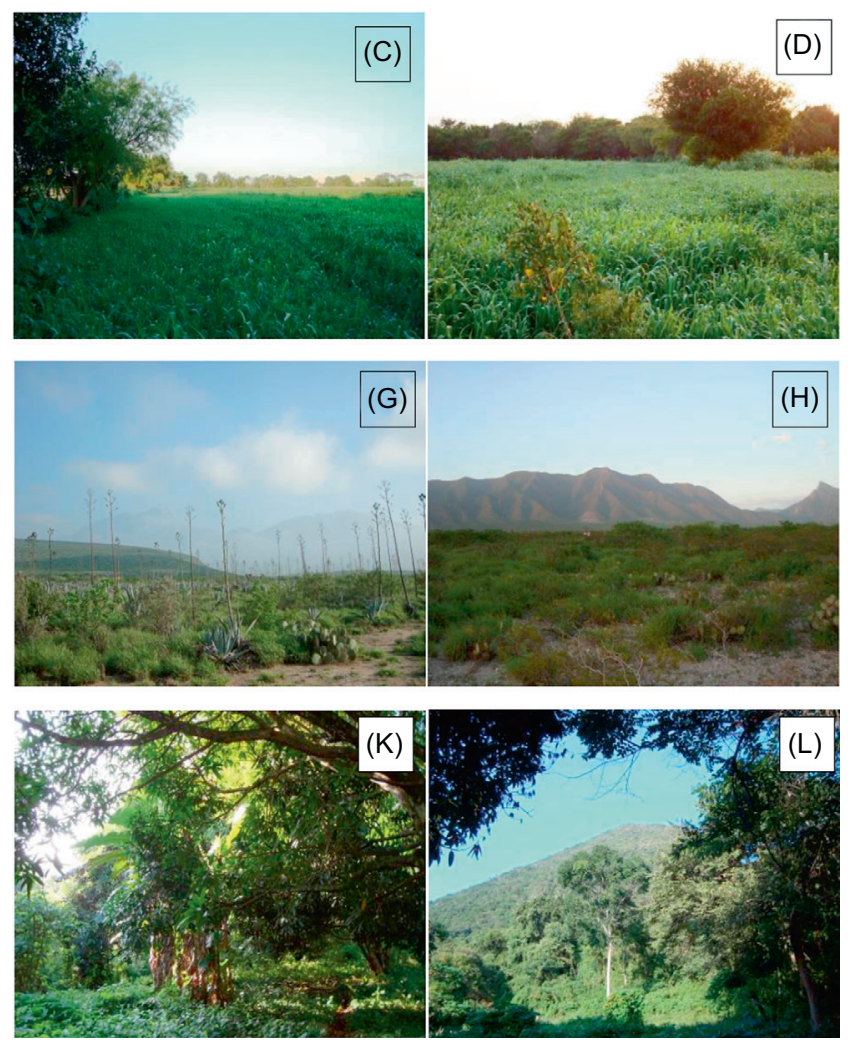

Figure 2. General landscape views of study sites in the states of Nuevo León and Tamaulipas. Nuevo León: Linares, Rancho San Manuel (A and B); Escobedo, Ejido San Nicolás, Predio Colectivo Viejo (C and D); Santiago, Ciénega de González (E and F); Mina, Ejido Labores del Ojo (G and H); Cadereyta Jiménez, Fraccionamiento Rincón de los Sabinos Second Sector (I and J); and the state of Tamaulipas: Gómez Farías (K and $\mathrm{L})$. 


\section{Sandfly collection and processing}

Phlebotomine sandflies were captured using CDC light $\operatorname{traps}^{\circledR}$ (model 512; John W. Hock Co., Gainesville, FL, USA) [81]. Each CDC light trap was hung at a height of $1.5 \mathrm{~m}$ above the ground. These traps were operated from 18:00 to $07: 00 \mathrm{~h}$. A total $16 \mathrm{CDC}$ light traps were used per night at each site, where, depending on the features of the site, we distributed the traps along a single straight transect or following the contours of a creek. In all cases, traps were positioned at $25 \mathrm{~m}$ intervals from each other. We also used six aluminum trays $(50 \times 50 \mathrm{~cm})$, known as Disney traps [17], per night at each site, which were coated with a thin layer of castor oil and baited with BALB/c female mice. Each morning, captured sandflies were placed in an airtight container and a small ball of cotton wool was impregnated with ether as a killing agent. Specimens were then sorted and separated from other insects collected in the same traps. All caught insects were placed onto a white plastic tray. A pair of fine tweezers was used to separate sandfly specimens that were then preserved in plastic vials containing $70 \%$ ethanol. Approximately $20 \%$ of the caught females were individually preserved in $250 \mu \mathrm{L}$ Eppendorf vials containing $200 \mu \mathrm{L}$ of grade analysis ethanol. On arrival at the laboratory facilities, all samples were kept in a $-20{ }^{\circ} \mathrm{C}$ freezer until they were processed. Sandfly processing was conducted following standard curatorial techniques [34, 92], while identification was carried out using as a reference Young and Duncan [93] and Ibáñez-Bernal $[35,36]$. Phlebotomine sandflies species reported herein follow the classical nomenclature system of Lewis et al. [46]. Voucher specimens are held at the Medical Entomology Laboratory (UANL).

\section{Rodent collection and processing}

Rodents were only collected at localities in the state of Nuevo León. No collections were made in Gómez Farías, Tamaulipas due to heavy rains. Small rodents were collected using 30 collapsible live Sherman traps ${ }^{\circledR}$ per night. Each trap was baited with a mix of oat flakes impregnated with vanilla essence. All traps were set at ground level at intervals of $25 \mathrm{~m}$ on a single transect per site. All captured rodents were taxonomically identified and sexed. For these individuals, we also recorded standard body measurements and weight. Each individual was sacrificed and processed to obtain tissue samples of the skin surrounding the tail, biopsies of the ears, liver, spleen, and heart. All tissues were coded and were preserved in $2 \mathrm{~mL}$ sterile Eppendorf vials containing 70\% ethanol. All tissues were kept in a $-20{ }^{\circ} \mathrm{C}$ freezer until they were processed for molecular analyses. For the analysis of Leishmania infection among rodent species, we included specimens captured at several collections conducted in the state of Nuevo León; however, to compare diversity among sites, we only included those sites with the same trapping effort. Specimens were handled and euthanized according to the guidelines of the American Society of Mammalogists for the use of wild mammals in research [22], and under a collecting permit issued by the General Directorate of Wildlife of Mexico (permission number SGPA/DGVS/00471/11). Voucher specimens are held at the Medical Entomology Laboratory (UANL).

\section{Analysis of diversity in sandfly and rodent assemblages}

For alpha diversity, Chao1-bc (bias-corrected form for the Chaol estimator) [6,7], exponential of Shannon entropy index, and inverse of Simpson concentration index were estimated and called Hill numbers [31] with order $q=0,1,2$, respectively. The diversity of order $q$ indicates its sensitivity to common and rare species [38]. The diversity of order zero $(q=0)$ is completely insensitive to species abundance and is known as species richness of an assemblage; when $q=1$, the weight for all species is mainly due to their abundance and therefore does not favor either common or rare species; and when $q=2$, the major weight is placed on the most common species [38]. These indices have the intuitive properties (principle of duplication and replication) expected of diversity [38-40]. Hill numbers unify the diversity measured combining several in one expression called "effective number of species" that allows us to compare the magnitude of the difference in the diversity of two or more communities [31, 38, 47]. The estimator Chao1-bc $(q=0)$ uses only the numbers of singletons and doubletons to estimate the number of undetected species in the sample [8]. Individual-based abundance data and the Maximum Likelihood Estimator (MLE) were used. A bootstrap procedure of 100 replications was applied to obtain variances and to construct the confidence intervals of estimated diversities. These three estimates were calculated by the online program SpadeR (Species Prediction and Diversity Estimation) [7]. For Clench's equation [12], it estimates the total number of species in relation to trapping effort. The software program was set at 100 randomizations of the dataset before analysis in EstimateS version 9.1.0 [13]. Then, nonlinear regressions with Simplex and Quasi-Newton logarithms in STATISTICA software, v. 10.0 (StatSoft Inc. USA) were used in this equation $[37,76]$. For beta diversity, Jaccard's similarity index was used, and the binary data (presence/absence) were analyzed using the Multi-Variate Statistical Package (MVSP v. 3.22). Using Jaccard's coefficients, a dendrogram was constructed by Unweighted Pair Group Method Average (UPGMA).

The co-occurrence of rodent and sandfly species was evaluated using a C-Score model [80] with the software EcoSim (v. 7.72) [28]. The C-Score model requires data on presence (1) and absence (0), and before analyses 5,000 randomizations were carried out. If the observed value of the model is greater than the simulated value, then a segregated pattern is established. In contrast, if the observed value is less than the simulated model, then an aggregated pattern is established. Finally, if the observed and simulated values are equal, then a random co-occurrence is established $[9,10]$. A Z-statistic was calculated to test the null hypothesis that sandfly sex proportions were equal in the samples. To test whether there was a significant association between species (insects and rodents) and the study sites, we compared the relative abundances by $\chi^{2}$ analyses using a $c \times r$ table. All statistical tests were considered significant if $p<0.05$ [76]. 


\section{Molecular analysis of Leishmania strains in sandfly and rodent samples}

DNA from rodent tissues was extracted from approximately $25 \mathrm{mg}$ of tissues, using a commercial DNA extraction kit (DNeasy ${ }^{\circledR}$ Blood and Tissue kit, Qiagen, Hilden, Germany), following the manufacturer's instructions. The DNA was analyzed by PCR. For sandfly analysis, the abdomen and thorax of individual females were used for DNA extraction, using a modified plasmid extraction Sambrook protocol [72] and Pech-May et al. method [58]. The DNA pellets were resuspended in $30 \mu \mathrm{L}$ distilled water and $50 \mathrm{ng}$ DNA was subjected to PCR amplification.

To determine the presence of Leishmania, we used oligonucleotides based on the Leishmania mini-circle kinetoplast DNA, L.MC-1S, and L.MC-1R [41]. Identification of Leishmania (L.) mexicana species was done using the small subunit of the $18 \mathrm{~S}$ ribosomal gene as forward primer IR1 (designed by Cupolillo [15]), and the internal transcribed spacer of the ribosomal RNA (rRNA) gene as reverse primer LM17 [3]. Amplification reactions were done in $50 \mu \mathrm{L}$ of reaction mixture: Taq PCR Master Mix (Qiagen, Hilden, Germany), $100 \mathrm{ng}$ of the corresponding oligonucleotides, and $1 \mu \mathrm{L}$ of tissue extract corresponding to $100 \mathrm{ng}$ of DNA, or $50 \mathrm{ng}$ of DNA from Lutzomyia. The amplification was carried out in a Perkin Elmer 2720 thermocycler using different conditions, depending on the oligonucleotides used. For L.MC-1S/L.MC-1R (Leishmania genus), 30 cycles at $95{ }^{\circ} \mathrm{C}$ for $1 \mathrm{~min}$ (denaturation), $55^{\circ} \mathrm{C}$ for $1 \mathrm{~min}$ (annealing), and $72{ }^{\circ} \mathrm{C}$ for $1 \mathrm{~min}$ (polymerization) were used. For IR1/LM17 (Leishmania (L.) mexicana), 35 cycles at $94{ }^{\circ} \mathrm{C}$ for $1 \mathrm{~min}$, at $65^{\circ} \mathrm{C}$ for $1 \mathrm{~min}$, and at $72{ }^{\circ} \mathrm{C}$ for $1 \mathrm{~min}$ were used. In all cases, the cycles were preceded by a cycle at $94{ }^{\circ} \mathrm{C}$ for $5 \mathrm{~min}$ and a final extension cycle at $72{ }^{\circ} \mathrm{C}$ for $7 \mathrm{~min}$. As a positive control for Lutzomyia DNA extraction, a conserved region of the $18 \mathrm{~S}$ rRNA gene (450 bp) was used. PCR was carried out using Lu.18S rRNA-1S (5'-TGCCAGTAGTTATATGCTTG- $\left.3^{\prime}\right)$ and Lu.18S rRNA-1R (5'-TTACGCGCCTGCTGCCTTCC-3') [41]. The amplification conditions were the same as described for Leishmania genus. PCR products were analyzed in $1.5 \%$ agarose gel electrophoresis in Tris-acetateEDTA (TAE) buffer at $80 \mathrm{~V}$, stained with $0.5 \mu \mathrm{g} / \mathrm{mL}$ ethidium bromide, and visualized under ultraviolet light.

\section{Analysis of Ecological Niche Modeling of rodent and sandfly distribution}

We built the ecological niche of infected rodents and sandflies and projected them to generate the potential distribution models of the infected-rodent and sandfly species (IRSS) captured. We modeled IRSS potential distribution to determine the geographic and ecological extent of leishmaniasis using as predictors both rodents confirmed as infected by Leishmania (by this study) and potential vectors. With this approach, we can provide information about a large unsampled region. We used the Global Biodiversity Information Facility (GBIF) public database and the occurrence data of the different species provided by the laboratory of Geographic Information Systems of the National Autonomous University of Mexico.
We modeled only those IRSS that have more than 10 independent georeferenced data, and used nine WorldClim bioclimatic variables that could determine the IRSS' presence (www.worldclime.com). Variables used were: annual mean temperature, temperature seasonality, mean temperature of warmest quarter, mean temperature of coldest quarter, annual precipitation, precipitation of the driest month, precipitation seasonality, precipitation of driest quarter, and altitude. As regional models tend to overfit the data, we used only the biogeographic provinces that covered our region of interest (i.e. NEM and the Southeast of the USA). To implement the models, we used the MaxEnt algorithm, which has proven to be robust in the predictions of the potential distribution of species [54]. To build the models, $75 \%$ of data were used to train the models and $25 \%$ were used as test data. We created 100 replicates, then all models generated were analyzed one by one, and the best model for each species was chosen. The accuracy of each model was assessed using both the AUC (area under the receiver operating characteristic [ROC] curve), which is automatically generated by MaxEnt, and the 11 binomial tests of model performance, which are reported as part of the MaxEnt output. All 11 binomial tests were required to be significant at a confidence level of $p<0.01$, which is also a conservative choice. We considered only those niche models possessing both a $p$ value less than 0.01 for the binomial test of omission and an AUC greater than 0.80. It is a well-known fact that several rodent species have the potential to become crop pests, thereby increasing the risk of transmission to humans. To test whether or not there was an association between crop areas and the distribution of rodents, we overlapped the map of the three main crops in the region: sorghum, bean, and barley on the ENM of all rodents registered at the study sites.

\section{Results}

\section{Sandfly diversity}

During the sampling period (April to August 2010), we collected a total 724 specimens of sandflies comprising 13 species in two genera (Lutzomyia and Brumptomyia França and Parrot). Out of the total 724 sandflies, $11.88 \%$ (46 + and 40 \%) were collected in the state of Nuevo León and $88.12 \%$ (325 $q$ and $313 \widehat{\jmath})$ in the state of Tamaulipas (Table 2). We were able to collect sandfly specimens at all the selected sites with the exception of Mina. The most abundant species in the state of Nuevo León were Lu. texana (37.21\%) and Lu. diabolica (27.91\%). In the locality of Cadereyta Jiménez, we observed the highest species richness 6.96 (6.07-19.36), and 4.22 (3.63-4.81) effective species in the state of Nuevo León (Table 2). We also observed that in the same locality, the species Brumptomyia hamata (Fairchild and Hertig) repre-

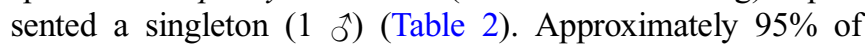
specimens were collected with CDC light traps, and the rest with Disney traps. Using a $Z$-statistic to test the hypothesis of equal proportion of sex, we concluded that the sex proportion (1:1 female:male) was not significantly different for the captures in Nuevo León (females $53.49 \%$ versus males 
Table 2. Species composition and total abundance and relative abundance (\%) of male and female phlebotomine sandflies caught in Nuevo León and Tamaulipas, Mexico. Estimated diversities of Chao1-bc $(q=0)$ (bias-corrected form for the Chaol estimator), exponential of Shannon entropy index $(q=1)$, and inverse of Simpson concentration index $(q=2)$, with its confidence intervals based on a bootstrap method of 100 replications. Collections were conducted from April to August 2010.

\begin{tabular}{|c|c|c|c|c|c|c|c|c|c|c|c|}
\hline \multirow[b]{3}{*}{ Species } & \multicolumn{8}{|c|}{ Nuevo León } & \multirow{2}{*}{\multicolumn{2}{|c|}{$\begin{array}{c}\text { Tamaulipas } \\
\text { Gómez Farías } \\
\end{array}$}} & \multirow[b]{3}{*}{ Total $(\%)$} \\
\hline & \multicolumn{2}{|c|}{ Linares } & \multicolumn{2}{|c|}{ Escobedo } & \multicolumn{2}{|c|}{ Santiago } & \multicolumn{2}{|c|}{ Cadereyta } & & & \\
\hline & $\hat{0}$ & 운 & $\hat{0}$ & 운 & $\hat{0}$ & q & $\hat{0}$ & 운 & $\hat{0}$ & 우 & \\
\hline Brumptomyia hamata & 0 & 0 & 0 & 0 & 0 & 0 & 1 & 0 & 0 & 0 & $1(0.14)$ \\
\hline Brumptomyia mesai & 0 & 0 & 0 & 0 & 0 & 0 & 2 & 3 & 0 & 0 & $5(0.69)$ \\
\hline Lutzomyia anthophora & 0 & 0 & 0 & 3 & 0 & 0 & 0 & 6 & 1 & 0 & $10(1.38)$ \\
\hline Lutzomyia cratifer & 0 & 0 & 0 & 0 & 0 & 0 & 0 & 0 & 2 & 6 & $8(1.10)$ \\
\hline Lutzomyia cruciata & 0 & 1 & 0 & 0 & 0 & 0 & 0 & 1 & 1 & 193 & $196(27.07)$ \\
\hline Lutzomyia ctenidophora & 0 & 0 & 0 & 0 & 0 & 0 & 0 & 0 & 0 & 2 & $2(0.28)$ \\
\hline Lutzomyia diabolica & 0 & 0 & 0 & 0 & 14 & 10 & 0 & 0 & 0 & 0 & $24(3.31)$ \\
\hline Lutzomyia leohidalgoi & 0 & 0 & 0 & 0 & 0 & 0 & 0 & 0 & 0 & 2 & $2(0.28)$ \\
\hline Lutzomyia oppidana & 0 & 0 & 0 & 0 & 0 & 0 & 0 & 0 & 2 & 3 & $5(0.69)$ \\
\hline Lutzomyia shannoni & 0 & 0 & 0 & 0 & 1 & 0 & 0 & 0 & 306 & 117 & $424(58.56)$ \\
\hline Lutzomyia texana & 8 & 7 & 0 & 0 & 0 & 0 & 6 & 11 & 0 & 2 & $34(4.70)$ \\
\hline Lutzomyia trinidadensis & 0 & 0 & 0 & 0 & 0 & 0 & 0 & 0 & 1 & 0 & $1(0.14)$ \\
\hline Lutzomyia vindicator & 0 & 2 & 0 & 0 & 0 & 0 & 8 & 2 & 0 & 0 & $12(1.66)$ \\
\hline Number of individuals & 8 & 10 & 0 & 3 & 15 & 10 & 17 & 23 & 313 & 325 & $724(100)$ \\
\hline Number of species & & & \multicolumn{2}{|l|}{10} & \multicolumn{2}{|c|}{6} & \multicolumn{2}{|c|}{9} & 13 \\
\hline Estimator Chaol-bc & \multicolumn{2}{|c|}{$3.00(3.00-5.00)$} & \multicolumn{2}{|c|}{$1.00(1.00-1.00)$} & \multicolumn{2}{|c|}{$2.00(2.00-2.00)$} & \multicolumn{2}{|c|}{$6.96(6.07-19.36)$} & \multicolumn{2}{|c|}{$9.25(9.00-13.80)$} & $13.33(13.00-19.00)$ \\
\hline Exponential of Shannon entropy index & \multirow{2}{*}{\multicolumn{2}{|c|}{$\begin{array}{l}1.75(0.97-2.52) \\
1.41(0.80-2.02)\end{array}$}} & \multirow{2}{*}{\multicolumn{2}{|c|}{$\begin{array}{l}1.00(1.00-1.00) \\
1.00(1.00-1.00)\end{array}$}} & \multirow{2}{*}{\multicolumn{2}{|c|}{$\begin{array}{l}1.18(0.89-1.47) \\
1.08(-1.58-3.75)\end{array}$}} & \multicolumn{2}{|c|}{$4.22(3.63-4.81)$} & \multicolumn{2}{|c|}{$2.23(2.09-2.37)$} & $3.39(3.06-3.72)$ \\
\hline Inverse of Simpson concentration index & & & & & & & 3.5 & $7-4.31)$ & \multicolumn{2}{|c|}{$1.88(1.78-1.98)$} & $2.38(2.19-2.56)$ \\
\hline
\end{tabular}


46.51\%) $(Z=-1.16, p<0.27)$. At Gómez Farías, in the state of Tamaulipas, we found that Lu. shannoni $(66.30 \%)$ and Lu. cruciata (30.41\%) were the most common species. On the other hand, a singleton was observed for Lutzomyia trinidadensis (Newstead) (1 $\left.\begin{array}{l}1 \\ 1\end{array}\right)$. Although the majority of specimens were collected in CDC light traps, we also captured female sandflies $(28.37 \%)$ that were attracted to humans in Tamaulipas. We also tested the null hypothesis of equal proportions (female:male) in the catches carried out in the state of Tamaulipas (females $50.94 \%$ versus males $49.06 \%$ ), finding that there was no significant difference $(Z=-1.01, p=0.31)$.

Beta diversity using Jaccard's index indicated that the study sites of Linares and Cadereyta Jiménez were the most similar in terms of phlebotomine sandfly species (33\% and 50\%), respectively. The less similar study sites were Cadereyta Jiménez and Gómez Farías (Fig. 3A). Using combined data from Nuevo León and Tamaulipas for sandfly species abundances, we calculated the key parameters in Clench's equation. We found that the observed data fit well the expected values of the curves of species accumulation in relation with trapping effort. Nonetheless, we found that accumulation of species did not reach the predicted asymptote. Based on the intercept value $(a=2.43)$ and the slope value $(b=0.13)$, it was estimated that sandfly trapping effort was $70 \%$ and that we recorded 13 species out of the 18 predicted species (Fig. 4A). We also observed that sandfly species abundances were statistically associated with study sites, $\left(\chi^{2}=177.88\right.$, $d f=52, p<0.05)$, indicating a heterogeneity in spatial distribution in sandfly species richness. We found for sandfly species that the $C$-score value was 0.71 , as compared with $0.78( \pm 0.003)$ of the mean ( \pm variance of simulated $C$-score values) $(p=0.16)$. Estimations of the $C$-score show that the species exhibited neither an aggregated nor a segregated pattern.

\section{Rodent diversity}

A total 79 specimens of nine species were collected in all sampled sites. The most abundant species were Peromyscus maniculatus (Wagner) (37.97\%), Sigmodon hispidus Say and Ord (30.38\%), and Peromyscus leucopus Rafinesque (16.46\%). The highest species richness and abundances were found in Cadereyta Jiménez $(60.76 \%)$, where the most common species at this site were $S$. hispidus (41.66\%), P. maniculatus (29.17\%), and P. leucopus (16.66\%). Sampled among the species "singletons" were Dipodomys merriami Mearns, Heteromys irroratus (Gray), [63], and Peromyscus eremicus (Baird) (Table 3). The total number of species in the state of Nuevo León represents $75 \%$ of the total species richness estimated with Chao1-bc. The locality of Cadereyta had 1.58 times more diversity than Linares, and a little more than twice that in Escobedo, Santiago and Mina (Table 3). In the case of beta diversity, we found using Jaccard's index that Linares shared $25 \%$ similarity with Escobedo and Santiago; likewise, Escobedo shared 33\% similarity with Santiago and Cadereyta Jiménez (Fig. 3B).

Using the accumulation curve model of Clench's, we found that data from the state of Nuevo León showed a good fit
(A)

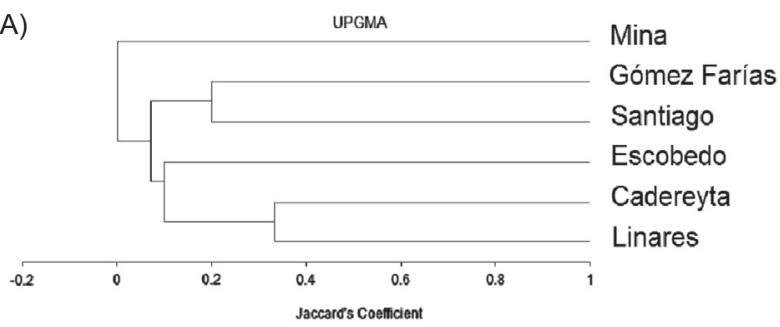

(B)

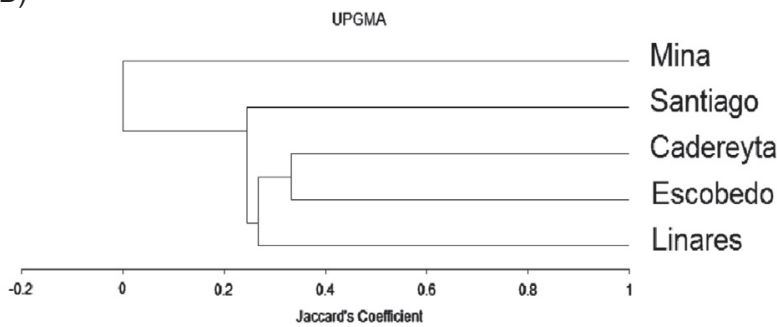

Figure 3. (A) Dendrogram according to Jaccard's similarity coefficient from phlebotomine sandflies, and (B) rodents collected in the states of Nuevo León and Tamaulipas, Mexico.
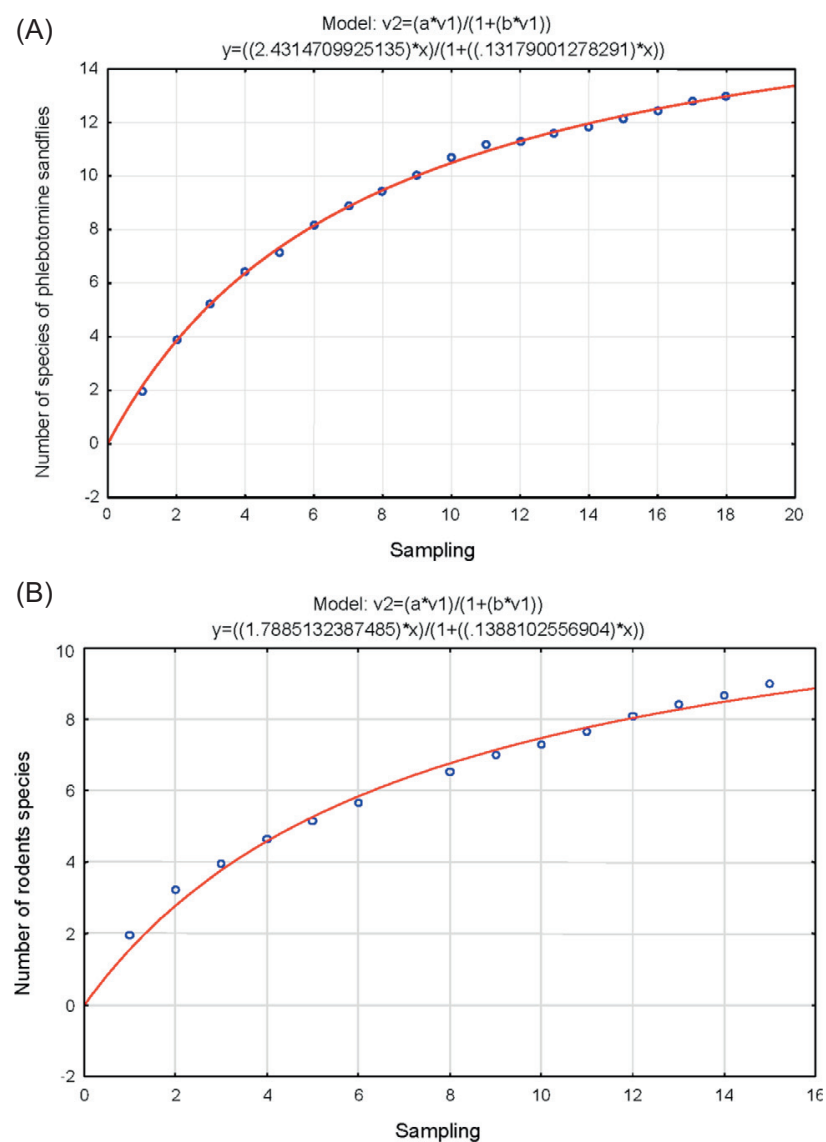

Figure 4. (A) Accumulation curve of species of phlebotomine sandflies, and (B) rodents species in Nuevo León and Tamaulipas, Mexico.

between observed and expected values. The key parameters of Clench's equation were the intercept $(a=1.78)$ and the slope $(b=0.13)$. With these values, it was estimated that 


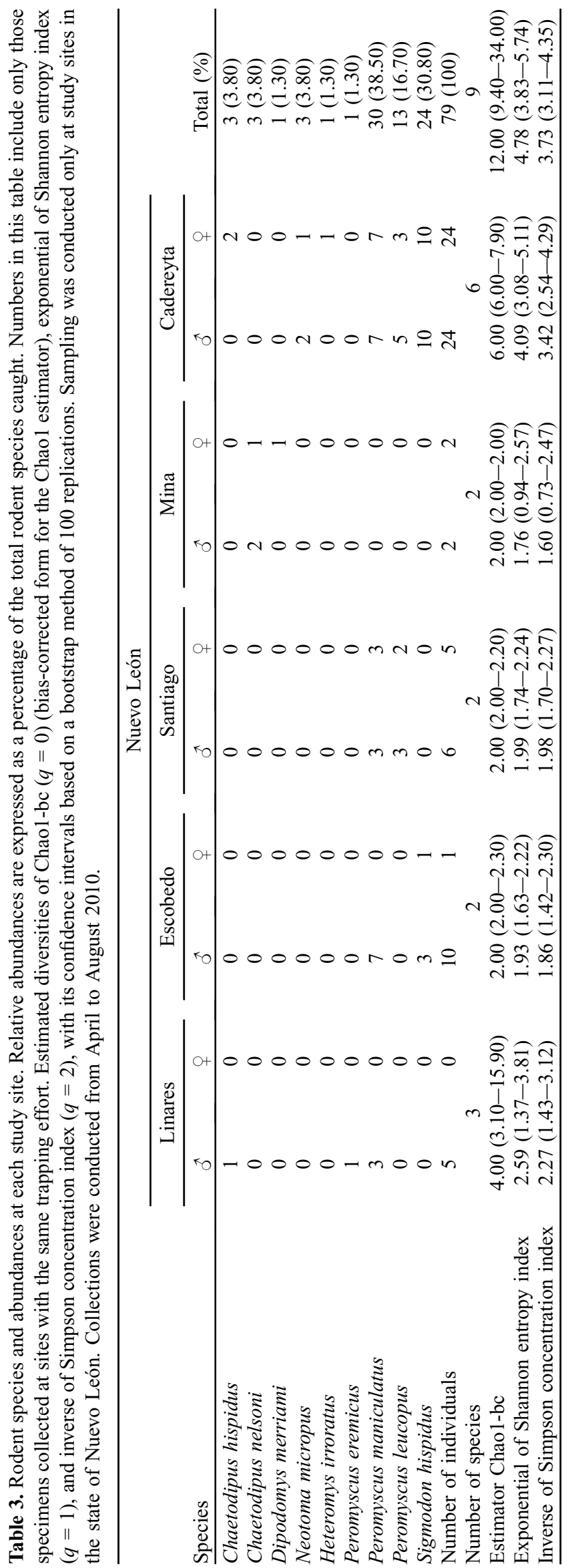

sampling effort was $69 \%$ with an observed number of species of nine and an expected number of 13 (Fig. 4B). It was found that abundances of rodents were spatially associated with study sites $\left(\chi^{2}=204.52, d f=32, p<0.05\right)$. We found for rodent species that value was 0.83 , as compared with $0.95( \pm 0.007)$ of the mean ( \pm variance of simulated $C$-score values) $(p=0.07)$. Estimations of the $C$-score show that species exhibit neither an aggregated nor a segregated pattern.

\section{Phlebotomine sandflies and rodents analyzed by PCR}

A total of 163 female sandfly specimens were individually analyzed by PCR, and were negative for Leishmania spp. Sandfly species tested were: Brumptomyia mesai (Sherlock) $(n=1)$, Lu. anthophora $(n=2)$, Lutzomyia cratifer (Fairchild and Hertig) $(n=1)$, Lu. cruciata $(n=98)$, Lu. diabolica $(n=1), L u$. oppidana $(n=2), L u$. shannoni $(n=48)$, Lu. texana $(n=8)$, and Lutzomyia vindicator (Dampf) $(n=2)$.

Tissues of collected rodents were tested by PCR to detect evidence of infection, finding that the species $P$. eremicus ( $n=1,100 \%)$, P. leucopus $(n=23,21.05 \%)$, P. maniculatus $(n=36,5.88 \%)$, and $S$. hispidus $(n=27,12.50 \%)$ were positive for genus-Leishmania parasites. The use of speciesspecific primers IR1/LM17 revealed that the infecting parasites were Leishmania (L.) mexicana (Table 4). For additional confirmation that the infecting parasites were Leishmania $(L$.) mexicana, the PCR amplifications obtained with the primers IR1/LM17 were sequenced at the Molecular Biology Unit of the Institute of Cellular Physiology, UNAM. The sequences were aligned with those from the National Center for Biotechnology Information, US National Library of Medicine, Basic Local Alignment Search Tool (BLAST). The gene sequences of our study showed a $99 \%$ identity with genes reported in GenBank under the accession numbers: Leishmania mexicana strain MHOM/MX/94/INDRE NBO (AF466381.1); Leishmania mexicana strain MHOM/MX/85/ SOLIS (AJ000313.1); Leishmania mexicana isolate 169 clone 1 (FJ948434.1); Leishmania mexicana strain MHOM/MX/84/ SET GS (AF466380.1); Leishmania mexicana strain MHOM/ MX/98/UNAM RR (AF466382.1); Leishmania mexicana strain MHOM/GT/86/GO22 (AJ000312.1); Leishmania mexicana isolate 7 clone 1 (FJ948433.1).

\section{Ecological Niche Modeling of rodent and sandfly distribution}

All nine rodent ENMs constructed had an average AUC of $0.90 \pm 0.0002$ and an accuracy that ranged from 0.80 to 0.97 . The observed distribution of nine rodents showed variation in their potential distribution. Chaetodipus species have a complementary potential distribution. Chaetodipus hispidus (Baird) possesses a northern distribution while Chaetodipus nelsoni Merriam has a southern distribution (Fig. 5). Peromyscus spp. also showed a potential distribution that covers the entire study area (Fig. 5). H. irroratus showed a southern distribution, while $S$. hispidus has a wide distribution nationwide. In particular for the study area, its distribution is related to the presence 
Table 4. Rodent species caught at several sites in the state of Nuevo León. Total numbers refer to the sample size analyzed by PCR for detection of Leishmania (L.) mexicana, whereas numbers between parentheses refer to the positive samples. Some specimens in this table were also obtained via sporadic collection.

\begin{tabular}{lcccc}
\hline Rodent species & Total & Prevalence (\%) & Biopsies $(+)$ & Sites of individuals \\
\hline Chaetodipus hispidus & $4(0)$ & 0 & - & LI $(n=2)$, CJ $(n=2)$ \\
Chaetodipus nelsoni & $3(0)$ & 0 & - & MI $(n=3)$ \\
Dipodomys merriami & $1(0)$ & 0 & - & MI $(n=1)$ \\
Neotoma micropus & $16(0)$ & 0 & - & CJ $(n=3), \mathrm{BU}(n=13)$ \\
Heteromys irroratus & $1(0)$ & 0 & - & $\mathrm{CJ}(n=1)$ \\
Perognathus flavus & $1(0)$ & 0 & $\mathrm{~L}$ & $\mathrm{BU}(n=1)$ \\
Peromyscus eremicus & $1(1)$ & 100.00 & $\mathrm{LI}(n=1)$ \\
Peromyscus leucopus & $19(4)$ & 21.05 & $\mathrm{~L}, \mathrm{~S}, \mathrm{H}$ & $\mathrm{BU}(n=3), \mathrm{SA}(n=5), \mathrm{CJ}(n=8), \mathrm{LI}(n=3)$ \\
Peromyscus maniculatus & $34(2)$ & 5.88 & $\mathrm{~L}, \mathrm{~S}, \mathrm{H}$ & $\mathrm{BU}(n=1), \mathrm{SA}(n=6), \mathrm{ES}(n=7), \mathrm{CJ}(n=14), \mathrm{LI}(n=6)$ \\
Peromyscus pectoralis & $2(0)$ & 0 & - & $\mathrm{LI}(n=2)$ \\
Reithrodontomys fulvescens & $1(0)$ & 0 & - & $\mathrm{BU}(n=1)$ \\
Sigmodon hispidus & $24(3)$ & 12.50 & $\mathrm{~L}, \mathrm{H}$ & $\mathrm{CJ}(n=1), \mathrm{ES}(n=4), \mathrm{CJ}(n=20)$ \\
Total & $107(10)$ & 9.35 & &
\end{tabular}

Abbreviation of biopsies: L: liver, S: spleen, and H: heart. Abbreviation of sites: LI: Linares, SA: Santiago, CJ: Cadereyta Jiménez, MI: Mina, ES: Escobedo, and BU: Bustamante.
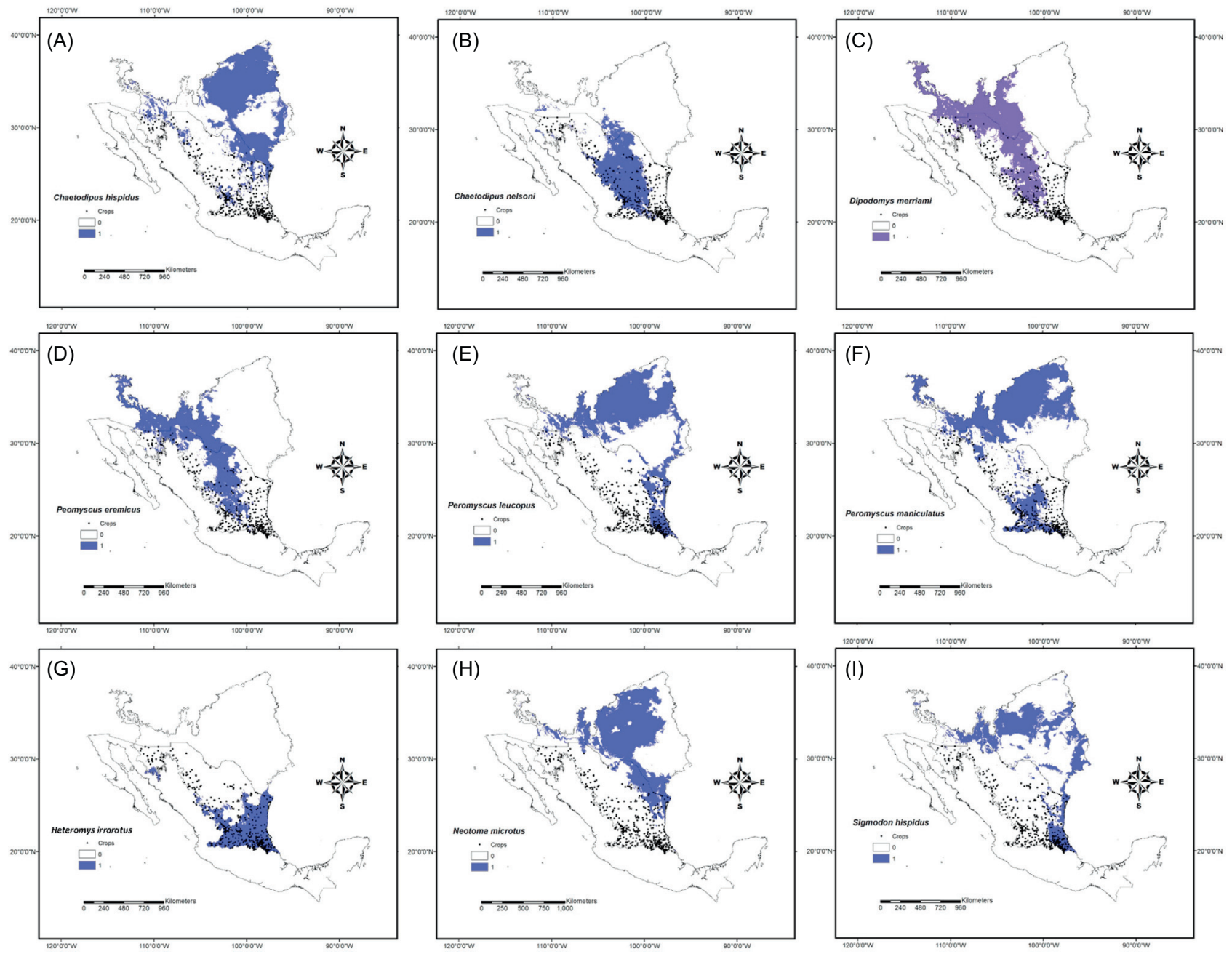

Figure 5. Ecological niche models of nine rodent species trapped and the geographic relation with crops in the Mexican area. 

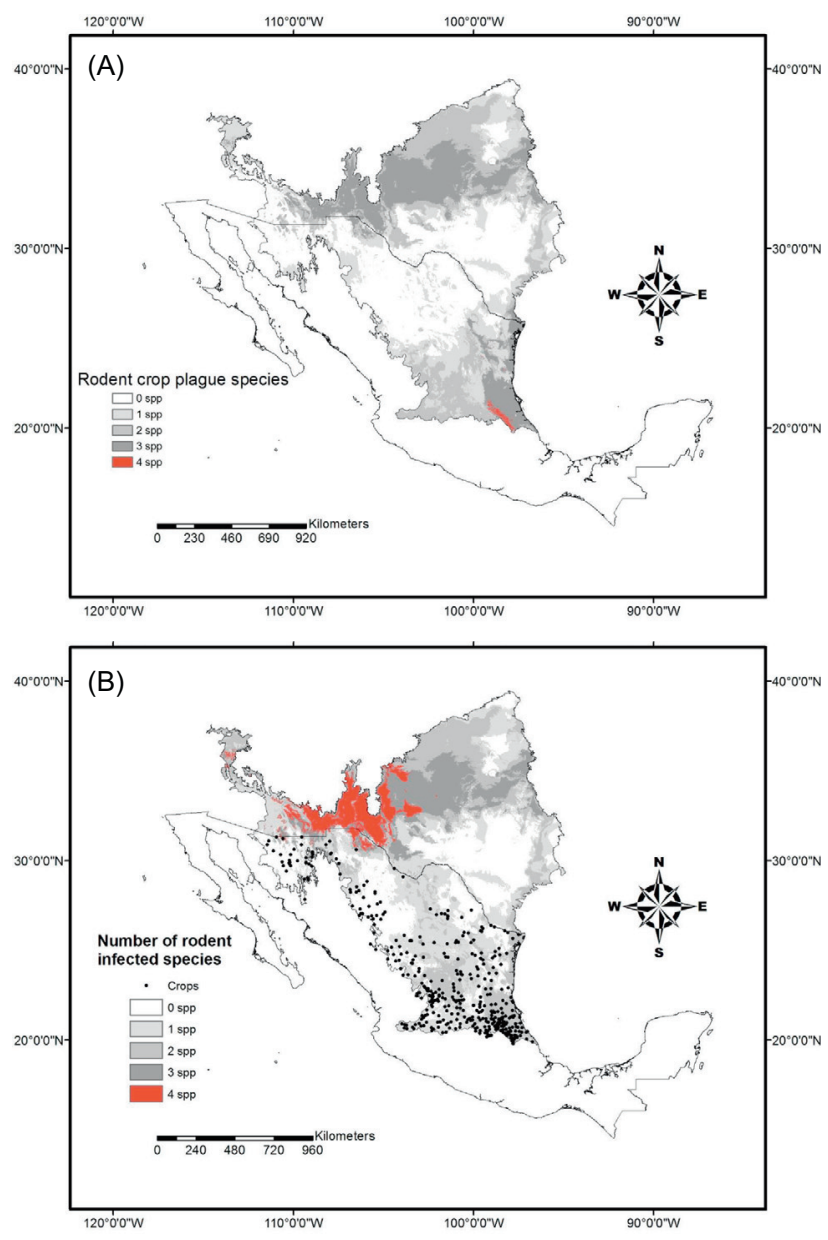

Figure 6. (A) Ecological niche models showing the geographic coincidence of the four rodent species caught during the study considered as crop plagues, and (B) the geographic coincidence of Leishmania-infected rodent species.

of crops. The species D. merriami and N. micropus showed a more northwestern distribution (Fig. 5). The four species considered crop pests showed a generalized regional potential distribution. According to the potential distribution models, the four species have similar occurrences in the southern part of the study area (Fig. 6A). Three of these four species (P. leucopus, P. maniculatus, and S. hispidus) were positive to Leishmania spp. parasites; these plus $P$. eremicus, also positive, showed a geographical coincidence in the northwestern part of the study area (Fig. 6B).

We made ENM models for only four Lutzomyia species, Lutzomyia texana, Lu. shannoni, Lu. trinidadensis, and $\mathrm{Lu}$. diabolica. The sandfly ENMs constructed had an average AUC of $0.97 \pm 0.004$ and an accuracy that ranged from 0.89 to 0.97 . Models showed a bias toward the Mexican territory due to the lack of georeferenced data from the US territory. Even this biased model showed that both Lutzomyia texana and $L u$. diabolica can potentially be found in USA. The integrated map for four Lutzomyia predicted the presence of the four species to the limits of Veracruz and Chiapas, Mexico, and two Lutzomyia species on the Mexican-US border
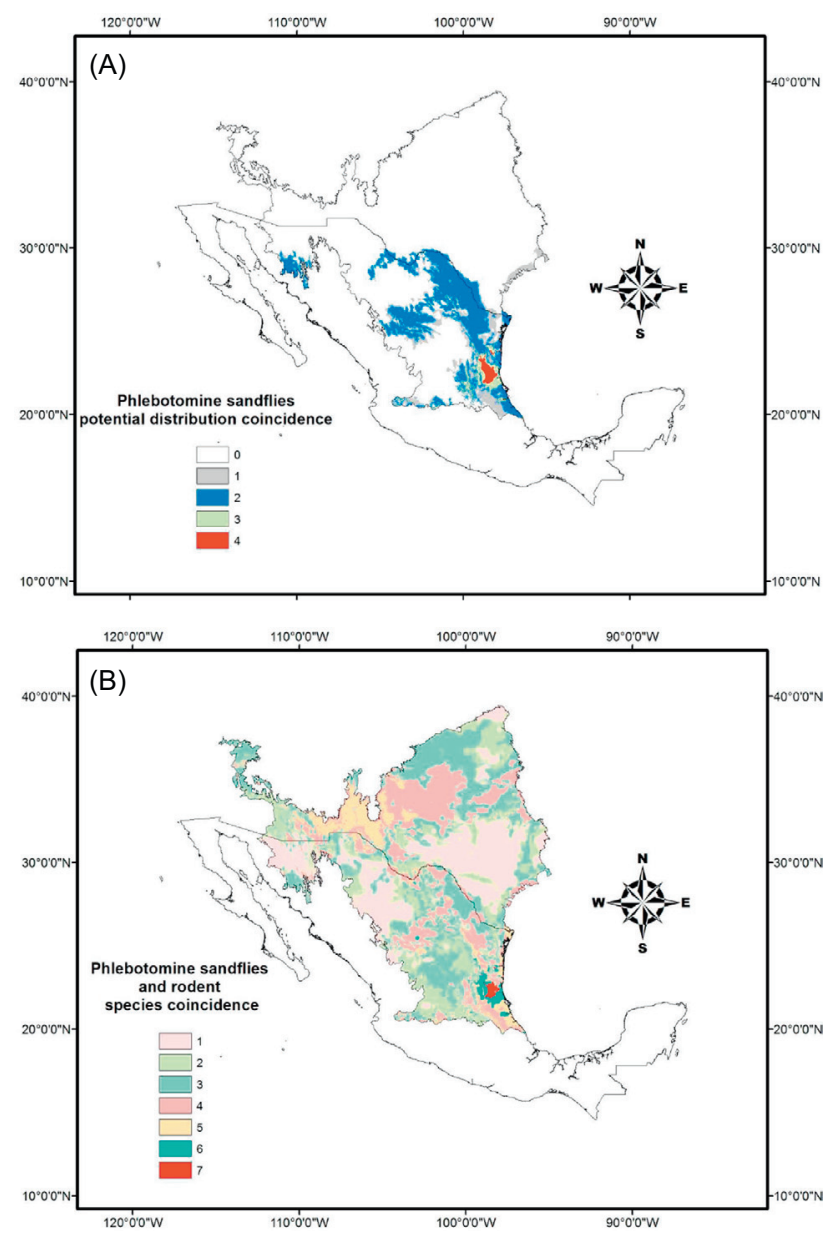

Figure 7. Potential distribution coincidence of four phlebotomine sandflies species (A), and Leishmania-infected rodent species (B). The red area shows the maximum coincidence at the southeast of the study area.

(Fig. 7A). The map integrating rodent and Lutzomyia species predicted south-Tamaulipas, Mexico as a place where infected-rodent species and Lutzomyia species could converge. The Mexican-US border is other area where at least one species of Lutzomyia and two of infected rodent coincide in their distributions (Fig. 7B).

\section{Discussion}

Prior to this study, the information available on the distribution of sandfly species or disease records was basically presence of data and it was not possible to interpret the information on an ecological basis. This study represents the first contribution conducted in NEM that simultaneously documents both phlebotomine sandfly species as well as rodent species. As we standardized the same number and type of traps and the trapping efforts at each study site, it was possible to make collection data comparable between sites. Furthermore, this paper also represents the first ever record of Leishmania (L.) mexicana infection among wild-caught rodents in the NEM region. 
Regarding phlebotomine sandfly fauna, our sampling effort detected 13 species, corresponding to $70 \%$ of the predicted species occurring in the NEM region according to Clench's equation, which predicts that a total of 18 species should occur in the region. Many species are common to those reported in the USA [86, 87, 92].

Although we did not find Leishmania infection in female sandflies, that does not represent evidence of absence of parasites. It is possible that infection rates among female sandflies are relatively low; and perhaps a larger sample has to be analyzed. Natural infection in the sandfly $L u$. anthophora has been reported to be $11.11 \%$ ( 3 out of 27 females) in collections made directly inside Neotoma nests in Bexar county, TX, USA [53]. In another study carried out in Bexar county, only one female $L u$. anthophora $(0.29 \%, 1$ out of 347) was found infected with Leishmania parasites [50]. These quoted studies indicate that Leishmania infection may vary considerably even at the same study sites. The reasons for this variation are currently unknown. Similarly, natural infection rates of sandfly species from Southeastern Mexico [57, 59, 73] have also been found to vary between species, sites, and months of collection. For instance, infection rates reported by Pech-May et al. [57] varied from overall values of 5.4-66.7\%; and for particular species, the infection rates were as follows: $\mathrm{Lu}$. cruciata $(25 \% ; n=1 / 4)$, Lu. olmeca olmeca $(14.3-40 \% ; n=5 / 35$; $n=15 / 35$, respectively), Lu. panamensis $(66.7 \% ; n=1 / 3)$, and $L u$. shannoni $(5.4-40.0 \%, n=(3 / 56) ; n=8 / 20$, respectively). Likewise, Sánchez-García et al. [73] also reported varied infection rates among Lu. cruciata $(100 \% ; n=6 / 6)$, Lu. olmeca olmeca (0.2-20\%), and Lu. shannoni (28.5\%; $n=2 / 7$ ). More recently, Pech-May et al. [59] reported a combined infection rate of $0.3 \%$ in Once de Mayo, Calakmul, Campeche. Infected flies were Lu. olmeca olmeca $(0.3 \%$; $n=1 / 342)$ and Lu. shannoni $(0.2 \%, n=1 / 412)$. For all the above reasons, we consider that to gain a better understanding of the natural infection rates, systematic and repetitive sampling needs to be undertaken in order to increase the chances of finding infected female sandflies. Despite the fact that we did not find natural Leishmania infection among the analyzed female sandflies, it is important to consider two interesting aspects: i) the presence of medically important species such Lu. cruciata, Lu. diabolica, Lu. anthophora, and Lu. shannoni; ii) Leishmania infection in wild mammals or humans occurs through the bite of an infected female sandfly. Thus, the infected rodents found in this study must have acquired an infection by some unknown sandfly vector. The role of vectors of Leishmania parasites by the above-mentioned species has been pointed out by several studies. For instance, Lu. anthophora is thought to be primarily an enzootic vector based on its close association with wood rats Neotoma micropus Baird [51]. Furthermore, Lu. anthophora has also been shown to transmit Leishmania parasites to experimental mice during blood feeding [20], and in Texas, Leishmania (L.) mexicana was isolated from wild-caught female $\mathrm{Lu}$. anthophora [50]. As Lu. anthophora tends to be more associated with Neotoma spp. rats, it has been suggested by McHugh et al. [51] that the sandfly Lu. diabolica is a more likely vector in the light of its marked anthropophily. Lu. diabolica is a suspected vector in Texas and apart from the ecological data, there is experimental evidence that female Lu. diabolica are capable of maintaining and achieving full development of Leishmania (L.) mexicana parasites [45]. Furthermore, experimental transmission bioassays have also been conducted with $\mathrm{Lu}$. diabolica, demonstrating the actual vector competence of females to transmit metacyclic promastigotes to hamsters [44]. With regard to the sandfly Lu. cruciata, there is growing evidence that this species could be an important vector of Leishmania spp. in southern Mexico, as this species has a large distribution area [26] and has been found naturally infected in several localities of Campeche [57, 59] and Quintana Roo [73]. Furthermore, this species is considered to be highly anthropophilic [4, 67], and it has been reported that Lu. cruciata is capable of transmitting Leishmania spp. parasites to hamsters under experimental conditions [90]. In the NEM region, Lu. cruciata is rarely found. However, to our knowledge, this species does occur in Texas and apparently, it is more commonly found in Florida [92]. Thus, the actual role of Lu. cruciata as a vector of Leishmania (L.) mexicana in NEM is yet to be determined in further studies. Another species with a large distribution area is Lu. shannoni, and it has been demonstrated that at least under laboratory conditions, female Lu. shannoni can harbor infectious stages of Leishmania (L.) mexicana [45]. In experimental bioassays, it has also been shown that infectious bites of laboratory-reared female $\mathrm{Lu}$. shannoni can lead to cutaneous lesions in hamsters [44]. Canine infections in the USA [74] are thought to be transmitted by $L u$. shannoni; however, no field data have been found to support the hypothesis put forward by Petersen [60, 61] and Petersen and Barr [62]. The role of the remaining species found in this study, as vectors of Leishmania parasites, remains an open question and although little evidence exists in the literature, the possibility that some of these species may actually transmit Leishmania parasites among other species of vertebrate hosts cannot be ruled out.

The alpha diversity indices we have used provide an ecological framework in which we can interpret the fact that the study site of Gómez Farías in the state of Tamaulipas had the highest effective number of species of phlebotomine sandflies. Results from the $\chi^{2}$ test $(r \times c)$ for association indicate that sandfly species are not evenly distributed over the study sites. As all sites varied in weather and/or vegetation types, however, it is not surprising that sandflies exhibited a heterogeneous pattern of distribution. Interestingly, results from beta diversity indices revealed that the similarity between sites was not associated with their proximity. For example, we found that two particular study sites (Santiago and Linares), that are geographically close to each other, did not share the same similarity in sandfly species. Other factors may affect the distribution of species and one possible factor could be the physical barrier of the mountains in the area. The presence of sandfly species at all study sites did not exhibit an aggregated pattern of co-occurrences and statistically, it was found that occurrences were random based on the C-score test. Of course, perhaps at the geographical scale of our study, species co-occurrences appear to be random, but if we consider a larger scale, it is possible that species co-occurrences could display an aggregated pattern.

For rodent species, it has been reported in several studies that, in Texas, Leishmania (L.) mexicana infection occurs in 
the wood rat $N$. micropus $[29,49,66]$ and in Neotoma floridana (Ord) [52]; whereas, in Arizona, Kerr et al. [43] reported Leishmania (L.) mexicana infection in two Neotoma albigula Hartley. In the present investigation, we did not find any infection in Neotoma rats with all infected animals belonging to the genera Sigmodon and Peromyscus. All 16 Neotoma micropus rats collected and analyzed in this study were negative for the presence of Leishmania infection. Prevalence of infection of $N$. micropus in Texas ranges from $5.6 \%$ to $27 \%$ [42]. In mark-release-recapture studies carried out in Bexar county, TX, Raymond et al. [66] also reported that prevalence of infection among $N$. micropus rats varied from $3.8 \%$ to $26.7 \%$. In our study, another interesting finding is that only S. hispidus was included in a list of 150 predicted mammal species with potential roles as hosts of Leishmania spp. [78]. In this list of potential reservoirs, S. hispidus was ranked number 27 with an epsilon value of 7.28 ; P. eremicus, $P$. leucopus, and $P$. maniculatus were not listed in this prediction list, and our findings would represent the first evidence of their putative role as reservoir hosts. A further risk model analysis of land cover variables and the co-occurrence of mammal species and sandfly species was conducted by González-Salazar et al. [27] indicating areas of low and high probability of transmission. According to these predictions, Leishmania-infected rodents found in this study overlap the areas of predicted high risk, which in turn indicates the power and validity of prediction models. In a more recent paper, Stephens et al. [79] expanded their model to the analysis of biotic networks among mammal and sandfly species. Therefore, the positive results of infection reported in this contribution fit those predictions well. At this stage, it is unclear why our results of infected rodents differ from those obtained in the Southern USA. One possibility is that studies in this region may perhaps have focused on Neotoma rats. Another possibility is that the southern USA in Texas bears more similarity with the northern counties of the Mexican states of Coahuila, Nuevo León, and Tamaulipas, and therefore it would be plausible that Neotoma spp. rats are more abundant in those areas. Our study sites in NEM were not really close to the border, so we do not know whether this factor plays a role. Alternatively, it is also probable that not many other species than Neotoma spp. have been screened for Leishmania infection in the USA. We analyzed tissues from all animals caught in the Sherman traps and did not focus our efforts on Neotoma spp. Interestingly, Kerr et al. [42] did not find Leishmania-positive individuals of $S$. hispidus, and suggested that the ecological association of Neotoma spp. rats and the sandfly vectors was one piece of evidence to support the hypothesis of the primary reservoir. Nevertheless, the most important point in our results is that they represent the first documented Leishmania (L.) mexicana infection in rodents in northern Mexico.

Over the last few years, there has been greater awareness of the disease in the state of Texas, with several authors pointing to an increase of known autochthonous cases of leishmaniasis there [11, 21, 48, 51, 91] in Oklahoma [11] and more recently, as far north as North Dakota [18]. In addition to the human cases reported in Texas, cutaneous and visceral leishmaniases have also been reported in $\operatorname{dogs}[19,61,74]$ and cats $[14,82]$. It is still debatable as to whether or not there has been an expansion of the disease, as suggested by Wright et al. [91], or alternatively that the recent reported cases may actually be a consequence of human intrusion into areas of enzootic cycles [53]. A more recent study, published by Moo-Llanes et al. [56], predicted the future distributions (2020, 2050, and 2080) of 28 Central and North American sandfly species under the scenario of climate change. From this later study, it was predicted that most sandfly species would increase their distribution areas to the north, and thereby more people would be at risk of acquiring leishmaniasis. In contrast with the knowledge and awareness of the disease in the USA by public health authorities, in Mexico, such awareness is largely absent.

Currently, the magnitude of the epidemiological risk to the inhabitants of the NEM region from leishmaniasis is unknown. Although officially no recent cases have been reported in NEM, this does not mean that cases do not exist. Taking into account: i) that historically there have been cases of leishmaniasis in NEM; ii) the confirmed L. mexicana infection in putative reservoir hosts; and iii) that medically important sandfly species do occur in the area, there is substantial evidence to indicate that Leishmania parasites may be maintained in the wild in enzootic cycles, and perhaps the real threat of an outbreak is yet to be evaluated.

Related to this is the fact that four of the nine species collected have been considered as crop plagues. In fact, one of the Leishmania-positive rodents was caught in a sorghum crop field. The potential distribution models showed that practically the entire study area is covered by more than one rodent species. Lutzomyia models are biased due to the lack of georeferenced data in the whole of the study area mainly in the northernmost part (USA). This highlights the need for more studies focusing on documenting phlebotomine sandflies fauna in border area. However, geographically speaking, suitable habitats exist for convergence of biological elements of the Leishmania cycle. The ENMs suggest that Leishmania parasites could have spread from South Mexico to NEM and the Southeastern USA. Even though it has been documented that Neotoma species have a positive relationship with Leishmania, our findings indicated that other rodent species could be potential reservoirs as well. In a relatively recent publication, Wright et al. [91] documented the spread of leishmaniasis toward North Texas. ENMs of species such as those of the Peromyscus group and those of Lu. texana clearly indicated that this geographic range extension of the Leishmania parasite would been occurring with the help of rodent species that nowadays are not only a natural element in the regional fauna but are recognized as crop pests as well.

Recently, it has been proposed that leishmaniasis is one of the poverty-linked diseases shared by Mexico and the USA, with poor housing identified as a relevant factor [32, 33]. However, the ecology and biogeography of the disease surely play a fundamental role in its dynamics and associated risk. In this context, it is important to mention that potential reservoir hosts can also be pests of several crops, a situation predicted in our ecological niche models. A spread of crop pests would potentially be a contributing factor in the emergence of leishmaniasis in this area. 


\section{Conflict of Interest}

The authors declare that they have no competing interests.

Acknowledgements. The authors are deeply grateful for field assistance from Ewry A. Zárate-Nahún and Fernando Rodríguez-Rojas. We are also grateful to the inhabitants of the localities in Nuevo León and Tamaulipas. We would also like to thank Dr. Sergio Ibáñez-Bernal for help in identifying sandfly species. We are also indebted to anonymous reviewers and one English linguistic editor that improved substantially our manuscript. This research received financial support from several projects: "Redes Ecológicas Complejas: Aplicaciones a las Enfermedades Emergentes y la Biodiversidad" (80156) (Conacyt, México) (Dr. Christopher Stephens), "Analisis de la dinamica y prevalencia de tres zoonosis emergentes en mamíferos pequeños silvestres en condiciones ambientales contrastantes" (DGAPA-Papiit, UNAM IN209314, PAPIIT IG200217) (Dr. V. Sánchez-Cordero), “Análisis Ecológico y de Distribución de los Insectos Vectores de las Enfermedades de Chagas y Leishmaniasis en el Noreste de México" (PAICYT, UANL SA341-10) (Dr. E. A. Rebollar-Téllez), and "Red de Diversidad y Conservación de Ecosistemas Naturales" (SEP-PROMEP, UANL-CA-121) Dr. Alejandro González).

\section{References}

1. Alvar J, Vélez ID, Bern C, Herrero M, Desjeux P, Cano J, Jannin J, den Boer M, the WHO Leishmaniasis Control Team. 2012. Leishmaniasis worldwide and global estimates of its incidence. PLoS One, 7, e35671.

2. Andrade-Narvaez FJ, Vargas-González A, Canto-Lara SB, Damian-Centeno AG. 2001. Clinical picture of cutaneous leishmaniases due to Leishmania (Leishmania) mexicana in the Yucatan Peninsula, Mexico. Memórias do Instituto Oswaldo Cruz, 96, 163-167.

3. Berzunza-Cruz M, Bricaire G, Salaiza SN, Pérez-Montfort R, Becker I. 2009. PCR for identification of species causing American cutaneous Leishmaniasis. Parasitology Research, 104, 691-699.

4. Biagi FF, de Biagi AM, Beltrán FH. 1965. Phlebotomus flaviscutellatus, transmisor natural de Leishmania mexicana. Prensa Medica Mexicana, 30, 267-272.

5. Chablé-Santos JB, Van Wynsberghe N, Canto-Lara SB, Andrade-Narvaez FJ. 1995. Isolation of Leishmania (L.) mexicana from wild rodents and their possible role in the transmission of localized cutaneous leishmaniasis in the state of Campeche, Mexico. American Journal of Tropical Medicine and Hygiene, 53, 141-145.

6. Chao A. 2005. Species estimation and applications, in Encyclopedia of Statistical Sciences. Balakrishnan N, Read CB, Vidakovic B, Editors. Wiley: New York. p. 7907-7916.

7. Chao A, Ma KH, Hsieh TC, Chiu CH. 2015. Online Program SpadeR (Species-richness Prediction And Diversity Estimation in R). Program and User's Guide published at http:// chao.stat.nthu.edu.tw/wordpress/software_download/

8. Chao A, Chun-Huo Ch. 2016. Nonparametric Estimation and Comparison of Species Richness. In: eLS. John Wiley \& Sons, Ltd: Chichester. p. 1-11.

9. Chaves LF, Añez N. 2004. Species co-occurrence and feeding behavior in sand fly transmission of American cutaneous leishmaniasis in western Venezuela. Acta Tropica, 92, 219-224.
10. Chaves LF. 2011. Phlebotomine sand fly species co-occurrence at the local scale: differences between agricultural and forested areas. Boletín de Malariología y Salud Ambiental, 51, 35-39.

11. Clarke CF, Bradley KK, Wright JH, Glowitz J. 2013. Case report: Emergence of autochthonous cutaneous leishmaniasis in northeastern Texas and southeastern Oklahoma. American Journal of Tropical Medicine and Hygiene, 88, 157-161.

12. Clench HK. 1979. How to make regional list of butterflies: Some thoughts. Journal of the Lepidopterists, 33, 216-231.

13. Colwell RK. 2009. EstimateS: Statistical estimation of species richness and shared species from samples. Version 8.2.0.

14. Craig TM, Barton CL, Mercer SH, Droleskey BE, Jones LP. 1986. Dermal leishmaniasis in a Texas cat. American Journal of Tropical Medicine and Hygiene, 35, 1100-1102.

15. Cupolillo E, Grimaldi GM Jr, Momen H, Beverley SM. 1995. Intergenic region typing (IRT): a rapid molecular approach to the characterization and evolution of Leishmania. Molecular and Biochemical Parasitology, 73, 145-155.

16. Díaz-Najera NA. 1971. Presence of Lutzomyia (Lutzomyia) diabolica (Hall, 1936) in Múzquiz, Coahuila, Mexico (Diptera, Psychodidae). Revista de Investigación en Salud Pública, 31, 62-66.

17. Disney RHL. 1966. A trap for Phlebotominae sand flies attracted to rats. Bulletin of Entomological Research, 56, 445-451.

18. Douvoyiannis M, Khromachou T, Byers N, Hargreaves J, Murray HW. 2014. Cutaneous leishmaniasis in North Dakota. Clinical Infectious Diseases, 59, e73-e75.

19. Duprey ZH, Steurer FJ, Rooney JA, Kirchhoff LV, Jackson JE, Rowton ED, Schantz PM. 2006. Canine Visceral Leishmaniasis, United States and Canada, 2000-2003. Emerging Infectious Diseases, 12, 440-446.

20. Endris RG, Young DG, Perkins PV. 1987. Experimental transmission of Leishmania mexicana by a North American sand fly Lutzomyia anthophora (Diptera: Psychodidae). Journal of Medical Entomology, 24, 243-247.

21. Furner BB. 1990. Cutaneous leishmaniasis in Texas: Report of a case and review of the literature. Journal of the American Academy of Dermatology, 23, 368-371.

22. Gannon WL, Sikes RS. 2007. Guidelines of the American Society of Mammalogists for the use of wild mammals in research. Journal of Mammalogy, 88, 809-823.

23. García E. 2004. Modificaciones al Sistema de Clasificación de Köppen: (Para adaptarlo a las condiciones de la República Mexicana). Instituto de Geografía, Universidad Nacional Autónoma de México, Distrito Federal, México: Quinta edición.

24. Godínez-Álvarez A, Ibáñez-Bernal S. 2010. Catálogo de Psychodidae (Diptera) de la Colección de Artrópodos con Importancia Medica del INDRE, Secretaria de Salud México. Acta Zoológica Mexicana, 26, 99-121.

25. González-Piñeyro DM, Arreola-Arredondo B, Gómez de Garza M, Welsh-Lozano O. 1993. Leishmaniasis en Nuevo León. Reporte de un caso. Dermatología Revista Mexicana, 37, 329-331.

26. González-Rosas C, Wang O, Strutz S, González-Salazar C, Sánchez-Cordero SarkarS. 2010. Climate change and risk of leishmaniasis in North America: predictions from ecological niche models of vector and reservoir species. PLoS Neglected Tropical Diseases, 4, e585.

27. González-Salazar C, Stephens CR. 2012. Constructing ecological networks: A tool to infer risk of transmission and dispersal of leishmaniasis. Zoonoses Public Health, 59, 179-193. 
28. Gotelli NJ, Entsminger GL. 2002. EcoSim: null models software for ecology. Version 7. Acquired Intelligence Inc. \& Kesey-Bear, Burlington, VT 05465.

29. Grog1 M, Kreutzer RD, McHugh CP, Martin RK. 1991. Characterization of a Leishmania isolate from the rodent host $N$. micropus collected in Texas and comparison with human isolates. American Journal of Tropical Medicine and Hygiene, 45, 714-722.

30. Hernández-Rivera MP, Hernández-Montes $\mathrm{O}$, Chiñas-Pérez A, Batiza-Avelar JM, Sánchez-Tejeda G, Wong-Ramírez C, Monroy-Ostria A. 2015. Study of cutaneous leishmaniasis in the state of Campeche (Yucatan Peninsula), Mexico, over a period of two years. Salud Pública de México, 57, 58-65.

31. Hill M. 1973. Diversity and evenness: a unifying notation and its consequences. Ecology, 54, 427-432.

32. Hotez PJ, Bottazzi ME, Dumonteil E, Valenzuela JG, Kamhawi S, Ortega J, Ponce de Leon-Rosales S, BetancourtCravioto M, Tapia-Conyer R. 2012. Texas and Mexico: sharing a legacy of poverty and neglected tropical diseases. PLoS Neglected Tropical Diseases, 6, e1497.

33. Hotez PJ. 2014. Ten global "hotspots" for the neglected tropical diseases. PLoS Neglected Tropical Diseases, 8, e2496.

34. Ibáñez-Bernal S. 1999. Phlebotominae (Diptera: Psychodidae) de México. I.- Brumptomyia França y Parrot; Lutzomyia França, las especies de L. (Lutzomyia) França y del grupo Verrucarum. Folia Entomologica Mexicana, 107, 61-116.

35. Ibáñez-Bernal S. 2005a. Phlebotominae (Diptera: Psychodidae) de México. V.- Clave Ilustrada para la identificación de los machos de Lutzomyia França. Folia Entomologica Mexicana, 44, 49-66.

36. Ibáñez-Bernal S. 2005b. Phlebotominae (Diptera: Psychodidae) de México. VI. Clave ilustrada para la identificación de las hembras de Lutzomyia França. Folia Entomologica Mexicana, 44, 195-212.

37. Jiménez-Valverde A, Hortal J. 2003. Las curvas de acumulación de especies y la necesidad de evaluar la calidad de los inventarios biológicos. Revista Ibérica de Aracnología, 8, 151-161.

38. Jost L. 2006. Entropy and diversity. Oikos, 113, 363-375.

39. Jost L. 2007. Partitioning diversity into independent alpha and beta components. Ecology, 88, 2427-2439.

40. Jost L. 2010. The relation between evenness and diversity. Diversity, 2, 207-232.

41. Kato H, Uezato H, Katakura K, Calvopiña M, Marco JD, Barroso PA, Gomez EA, Mimori T, Korenaga M, Iwata H, Nonaka S, Hashiguchi Y. 2005. Detection and identification of Leishmania species within naturally infected sand flies in the Andean areas of Ecuador by a polymerase chain reaction. American Journal of Tropical Medicine and Hygiene, 72, 87-93.

42. Kerr SF, McHugh CP, Dronen NO Jr. 1995. Leishmaniasis in Texas: prevalence and seasonal transmission of Leishmania mexicana in Neotoma micropus. American Journal of Tropical Medicine and Hygiene, 53, 73-77.

43. Kerr SF, McHugh CP, Merkeltz R. 1999. Short report: A focus of Leishmania mexicana near Tucson, Arizona. American Journal of Tropical Medicine and Hygiene, 61, 378-379.

44. Lawyer PG, Young DG. 1987. Experimental transmission of Leishmania mexicana to hamsters by bites of phlebotomine sand flies (Diptera: Psychodidae) from the United States. Journal of Medical Entomology, 24, 458-462.

45. Lawyer PG, Young DG, Butler JF, Akin DE. 1987. Development of Leishmania mexicana in Lutzomyia diabolica and
Lutzomyia shannoni (Diptera: Psychodidae). Journal of Medical Entomology, 24, 347-355.

46. Lewis D, Young DG, Fairchild GB, Minter DM. 1977. Proposals for a stable classification of the phlebotomine sandflies (Diptera: Psychodidae). Systematic Entomology, 2, 319-332.

47. MacArthur R. 1965. Patterns of species diversity. Biological Reviews, 40, 510-533.

48. Maloney DM, Maloney JE, Dotson D, Popov VL, Sanchez RL. 2002. Cutaneous leishmaniasis: Texas case diagnosed by electron microscopy. Journal of the American Academy of Dermatology, 47, 614-616.

49. McHugh CP, Grogl M, Kerr SF. 1990. Isolation of Leishmania mexicana from Neotoma micropus collected in Texas. Journal of Parasitology, 76, 741-742.

50. McHugh CP, Grogl M, Kreutzer RD. 1993. Isolation of Leishmania mexicana (Kinetoplastida: Trypanosomatidae) from Lutzomyia anthophora (Diptera: Psychodidae) collected in Texas. Journal of Medical Entomology, 30, 631-633.

51. McHugh CP, Melby PC, LaFon SG. 1996. Leishmaniasis in Texas: epidemiology and clinical aspects of human cases. American Journal of Tropical Medicine and Hygiene, 55, 547-555.

52. McHugh CP, Thies ML, Melby PC, Yantis LD Jr, Raymond RW, Villegas MD, Kerr SF. 2003. Short report: a disseminated infection of Leishmania mexicana in an eastern woodrat, Neotoma floridana, collected in Texas. American Journal of Tropical Medicine and Hygiene, 69, 470-472.

53. McHugh CP. 2010. Cutaneous leishmaniasis in Texas. Journal of the American Academy of Dermatology, 62, 508-510.

54. Merow C, Smith MJ, Silander JA. 2013. A practical guide to MaxEnt for modeling species' distributions: what it does, and why inputs and settings matter. Ecography, 36, 1058-1069.

55. Morrone JJ. 2001. Biogeografía de América Latina y el Caribe. M \& T-Manuales \& Tesis SEA, vol. 3. CYTED, ORCYTUNESCO \& SEA, Zaragoza.

56. Moo-Llanes D, Ibarra-Cerdeña CN, Rebollar-Téllez EA, Ibáñez-Bernal S, González C, Ramsey JM. 2013. Current and future niche of North and Central American sand flies (Diptera: Psychodidae) in climate change scenarios. PLoS Neglected Tropical Diseases, 7, e2421.

57. Pech-May A, Escobedo-Ortegón FJ, Berzunza-Cruz M, Rebollar-Téllez EA. 2010. Incrimination of four sandfly species previously unrecognized as vectors of Leishmania parasites in Mexico. Medical and Veterinary Entomology, 24, 150-161.

58. Pech-May A, Marina CF, Vázquez-Domínguez E, BerzunzaCruz M, Rebollar-Téllez EA, Narváez-Zapata JA, MooLlanes D, Ibáñez-Bernal S, Ramsey JM, Becker I. 2013. Genetic structure and divergence in populations of Lutzomyia cruciata, a phlebotomine sand fly (Diptera: Psychodidae) vector of Leishmania mexicana in southeastern Mexico. Infection, Genetics and Evolution, 16, 254-262.

59. Pech-May A, Peraza-Herrera G, Moo-Llanes DA, EscobedoOrtegón J, Berzunza-Cruz M, Becker-Fauser I, Montes De OcaAguilar AC, Rebollar-Téllez EA. 2016. Assessing the importance of four sandfly species (Diptera: Psychodidae) as vectors of Leishmania mexicana in Campeche, Mexico. Medical and Veterinary Entomology, 30, 310-320.

60. Petersen CA. 2009. Leishmaniasis, an emerging disease found in companion animals in the United States. Topics in Companion Animal Medicine, 24, 182-188. 
61. Petersen CA. 2009. New means of canine leishmaniasis transmission in North America: The possibility of transmission to humans still unknown. Interdisciplinary Perspectives on Infectious Diseases, 2009, 1-5.

62. Petersen CA, Barr SC. 2009. Canine leishmaniasis in North America: emerging or newly recognized? Veterinary Clinics of North America: Small Animal Practice, 39, 1065-1074.

63. Ramírez-Pulido J, González-Ruiz N, Gardner LA, ArroyoCabrales J. 2014. List of recent land mammals of Mexico. Museum of Texas Tech University Special Publications, 63, 1-69.

64. Ramos-Aguirre C. 1965. Reporte preliminar de un caso de leishmaniasis en la región Carbonífera de Coahuila (Botón de Oriente). Memorias III Congreso Mexicano de Dermatología: Monterrey, NL. p. 91-92.

65. Ramos-Aguirre C. 1970. Leishmaniasis en la región Carbonífera de Coahuila. Dermatología Revista Mexicana, $14,39-45$.

66. Raymond RW, McHugh CP, Witt LR, Kerr SF. 2003. Temporal and spatial distribution of Leishmania mexicana infections in a population of Neotoma micropus. Memórias do Instituto Oswaldo Cruz, 98, 171-180.

67. Rebollar-Téllez EA, Reyes-Villanueva F, Fernández-Salas I, Andrade-Narváez FJ. 1996a. Population dynamics and biting rhythm of the antropophilic sand fly Lutzomyia cruciata (Diptera: Psychodidae) in southeast Mexico. Revista do Instituto de Medicina Tropical de São Paulo, 38, 27-33.

68. Rebollar-Téllez EA, Reyes-Villanueva F, Fernández-Salas I, Andrade-Narváez FJ. 1996b. Abundance and parity rate of Lutzomyia cruciata (Diptera: Psychodidae) in an endemic focus of localized cutaneous leishmaniasis in Southern Mexico. Journal of Medical Entomology, 33, 683-685.

69. Rebollar-Téllez EA, Ramírez-Fraire A, Andrade-Narvaez FJ. 1996c. A two years study on vectors of cutaneous leishmaniasis: evidence for sylvatic transmission in the state of Campeche, Mexico. Memórias do Instituto Oswaldo Cruz, 91, 555-560.

70. Rebollar-Téllez EA, Orilla-Moguel H, Dzul-Manzanilla FA, Che-Mendoza A, Manrique-Saide P, Zapata-Peniche A. 2006. An update on the phlebotomid sand fly (Diptera: Phlebotomidae) fauna of Yucatan, Mexico. Entomological News, 117, 21-24.

71. Rzedowski J. 2006. Vegetación de México. 1ra. Edición digital, Comisión Nacional para el Conocimiento y Uso de la Biodiversidad, México.

72. Sambrook DJ, Fritsch EF, Maniatis T. 1989. Molecular cloning: A laboratory manual. Cold Spring Harbor Laboratory: Cold Spring Harbor, NY.

73. Sánchez-García L, Berzunza-Cruz M, Becker-Fauser I, Rebollar-Téllez EA. 2010. Sand flies naturally infected by Leishmania mexicana in the periurban area of Chetumal city, Quintana Roo, Mexico. Transactions of the Royal Society of Tropical Medicine and Hygiene, 104, 406-411.

74. Sellon RK, Menard MM, Meuten DJ, Lengerich EJ, Steurer FJ, Breitschwerdt EB. 1993. Endemic visceral leishmaniasis in a $\operatorname{dog}$ from Texas. Journal of Veterinary Internal Medicine, 7, 16-19.

75. Simpson MH, Mullins F, Stone OJ. 1968. Disseminated anergic cutaneous leishmaniasis. An autochthonous case in Texas and the Mexican states of Tamaulipas and Nuevo León. Archives of Dermatology, 97, 301-303.

76. Soberón J, Llorente J. 1993. The use of species accumulation functions for the prediction of species richness. Conservation Biology, 7, 480-488.
77. Sokal RR, Rohlf FJ. 1995. Biometry: The principles and practice of statistics in biological research, 3rd edn. W.H. Freeman: New York. 887 pp.

78. Stephens CR, Heau JG, González C, Ibarra-Cerdeña CN, Sánchez-Cordero V, González-Salazar C. 2009. Using biotic interaction networks for prediction in biodiversity and emerging diseases. PLoS One, 4, e5725.

79. Stephens CR, González-Salazar CR, Sánchez-Cordero V, Becker I, Rebollar-Téllez E, Rodríguez-Moreno A, Berzunza-Cruz M, Balcells CD, Gutiérrez-Granados G, Hidalgo-Mihart M, Ibarra-Cerdeña CN, Ibarra-López MP, Iñiguez-Dávalos LI, Ramírez-Martínez MM. 2016. Can you judge a disease host by the company it keeps? Predicting disease hosts and their relative importance: A case study for Leishmaniasis. PLoS Neglected Tropical Diseases, 10, e0005004.

80. Stone L, Roberts A. 1990. The checkerboard score and species distributions. Oecologia, 85, 74-79.

81. Sudia WD, Chamberlain RW. 1962. Battery operated light trap, an improved model. Mosquito News, 22, 126-129.

82. Trainor KE, Porter BF, Logan KS, Hoffman RJ, Snowden KF. 2010. Eight cases of feline cutaneous leishmaniasis in Texas. Veterinary Pathology, 47, 1076-1081.

83. Van Wynsberghe NR, Canto-Lara SB, Damián-Centeno AG, Itza-Ortiz MF, Andrade-Narváez FJ. 2000. Retention of Leishmania (Leishmania) mexicana in naturally infected rodents from the state of Campeche, Mexico. Memórias do Instituto Oswaldo Cruz, 95, 595-600.

84. Van Wynsberghe NR, Canto-Lara SB, Sosa-Bibiano EI, RiveroCárdenas NA, Andrade-Narváez FJ. 2009. Comparison of small mammal prevalence of Leishmania (Leishmania) mexicana in five foci of cutaneous leishmaniasis in the state of Campeche, Mexico. Revista do Instituto de Medicina Tropical de São Paulo, 51, 87-94.

85. Vargas-González A, Canto-Lara SB, Damian-Centeno AG, Andrade-Narváez FJ. 1999. Response of cutaneous leishmaniasis (chiclero's ulcer) to treatment with meglumine antimoniate in Southeast Mexico. American Journal of Tropical Medicine and Hygiene, 61, 960-963.

86. Vargas L, Diaz-Najera A. 1953a. Lista de flebótomos mexicanos y su distribución geográfica (Diptera: Psychodidae). Revista del Instituto de Salubridad y Enfermedades Tropicales, 13, 309-314.

87. Vargas L, Diáz-Nájera A. 1953b. Flebotomos comunes a México y a los Estados Unidos. Boletín de la Oficina Sanitaria Panamericana, 35, 494-498.

88. Velasco-Castrejón O, Savarino S, Neva F, Gúzman-Bracho C. 1989. Los agentes etiológicos de la leishmaniasis cutáneas en México. Presencia de L. braziliensis. Revista Latinoamericana de Microbiologia, 31, 231-234.

89. Welsh O. 1971. Leishmaniasis en Nuevo León. VI Congreso Mexicano de Dermatología, 78-80.

90. Williams P. 1966. Experimental transmission of Leishmania mexicana by Lutzomyia cruciata. Annals of Tropical Medicine and Parasitology, 60, 365-372.

91. Wright NA, Davis LE, Aftergut KS, Parrish ChA, Cockerell CJ. 2008. Cutaneous leishmaniasis in Texas: A northern spread of endemic areas. Journal of the American Academy of Dermatology, 58, 650-652.

92. Young DG, Perkins PV. 1984. Phlebotomine sand flies of North America (Diptera: Psychodidae). Mosquito News, 44, 263-304. 
93. Young D, Duncan M. 1994. Guide to the Identification and Geographic Distribution of Lutzomyia Sand Flies in Mexico, the West Indies, Central and South America (Diptera: Psychodidae). Memoirs of the American Entomological Institute no. 54, Gainesville, FLA, USA. 881 pp.
94. Zárate-Ramos JJ, Rodríguez-Tovar LE, Ávalos-Ramírez R, Salinas-Meléndez JA, Flores-Pérez FI. 2007. Description of a canine leishmaniasis clinical case in the north of Mexico. Veterinaria Mexico, 38, 231-240.

Cite this article as: Rodríguez-Rojas JJ, Rodríguez-Moreno Á, Berzunza-Cruz M, Gutiérrez-Granados G, Becker I, Sánchez-Cordero V, Stephens CR, Fernández-Salas I \& Rebollar-Téllez EA: Ecology of phlebotomine sandflies and putative reservoir hosts of leishmaniasis in a border area in Northeastern Mexico: implications for the risk of transmission of Leishmania mexicana in Mexico and the USA. Parasite, $2017,24,33$.

\section{PARASTE}

An international open-access, peer-reviewed, online journal publishing high quality papers on all aspects of human and animal parasitology

Reviews, articles and short notes may be submitted. Fields include, but are not limited to: general, medical and veterinary parasitology; morphology, including ultrastructure; parasite systematics, including entomology, acarology, helminthology and protistology, and molecular analyses; molecular biology and biochemistry; immunology of parasitic diseases; host-parasite relationships; ecology and life history of parasites; epidemiology; therapeutics; new diagnostic tools.

All papers in Parasite are published in English. Manuscripts should have a broad interest and must not have been published or submitted elsewhere. No limit is imposed on the length of manuscripts.

Parasite (open-access) continues Parasite (print and online editions, 1994-2012) and Annales de Parasitologie Humaine et Comparée (1923-1993) and is the official journal of the Société Française de Parasitologie. http://parasite.edmgr.com/ 